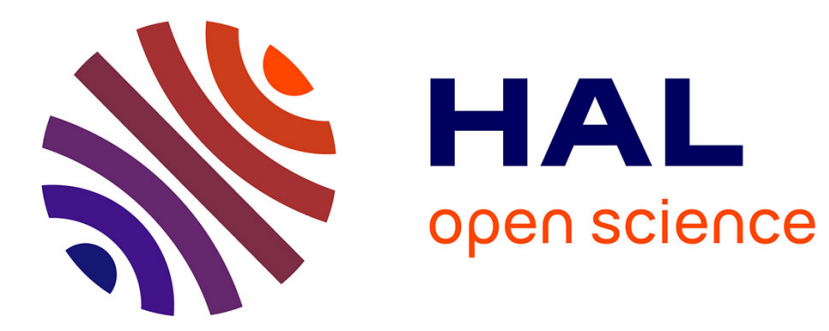

\title{
Site-Selective Ruthenium-Catalyzed C-H Bond Arylations with Boronic Acids: Exploiting Isoindolinones as a Weak Directing Group
}

Yu-Chao Yuan, Christian Bruneau, Thierry Roisnel, Rafael Gramage-Doria

\section{- To cite this version:}

Yu-Chao Yuan, Christian Bruneau, Thierry Roisnel, Rafael Gramage-Doria. Site-Selective Ruthenium-Catalyzed $\mathrm{C}-\mathrm{H}$ Bond Arylations with Boronic Acids: Exploiting Isoindolinones as a Weak Directing Group. Journal of Organic Chemistry, 2019, 84 (20), pp.12893-12903. 10.1021/acs.joc.9b01563 . hal-02322072

HAL Id: hal-02322072

https://hal-univ-rennes1.archives-ouvertes.fr/hal-02322072

Submitted on 21 Oct 2019

HAL is a multi-disciplinary open access archive for the deposit and dissemination of scientific research documents, whether they are published or not. The documents may come from teaching and research institutions in France or abroad, or from public or private research centers.
L'archive ouverte pluridisciplinaire HAL, est destinée au dépôt et à la diffusion de documents scientifiques de niveau recherche, publiés ou non, émanant des établissements d'enseignement et de recherche français ou étrangers, des laboratoires publics ou privés. 
Site-Selective Ruthenium-Catalyzed C-H Bond Arylations with Boronic Acids: Exploiting Isoindolinones as a Weak Directing Group Yu-Chao Yuan, Christian Bruneau, Thierry Roisnel, and Rafael Gramage-Doria J. Org. Chem., Just Accepted Manuscript • DOI: 10.1021/acs.joc.9b01563 • Publication Date (Web): 01 Aug 2019 Downloaded from pubs.acs.org on August 7, 2019

\section{Just Accepted}

"Just Accepted" manuscripts have been peer-reviewed and accepted for publication. They are posted online prior to technical editing, formatting for publication and author proofing. The American Chemical Society provides "Just Accepted" as a service to the research community to expedite the dissemination of scientific material as soon as possible after acceptance. "Just Accepted" manuscripts appear in full in PDF format accompanied by an HTML abstract. "Just Accepted" manuscripts have been fully peer reviewed, but should not be considered the official version of record. They are citable by the Digital Object Identifier (DOI@). "Just Accepted" is an optional service offered to authors. Therefore, the "Just Accepted" Web site may not include all articles that will be published in the journal. After a manuscript is technically edited and formatted, it will be removed from the "Just Accepted" Web site and published as an ASAP article. Note that technical editing may introduce minor changes to the manuscript text and/or graphics which could affect content, and all legal disclaimers and ethical guidelines that apply to the journal pertain. ACS cannot be held responsible for errors or consequences arising from the use of information contained in these "Just Accepted" manuscripts. 


\title{
Site-Selective Ruthenium-Catalyzed C-H Bond Arylations with Bo- ronic Acids: Exploiting Isoindolinones as a Weak Directing Group
}

\author{
Yu-Chao Yuan, Christian Bruneau, Thierry Roisnel, and Rafael Gramage-Doria* \\ Univ Rennes, CNRS, ISCR-UMR6226, F-3500o Rennes, France
}

\begin{abstract}
:
Biologically relevant $N$-arylisoindolinones efficiently underwent arylation reactions under ruthenium catalysis via C-H bond functionalization. The reactions exclusively led to mono-arylated products and only ortho selectivity was observed in the aromatic ring connected to the nitrogen atom. Interestingly, no $\mathrm{C}-\mathrm{H}$ bond functionalization was observed in the other benzene ring being in ortho position with respect to the carbonyl group. This ruthenium-catalyzed reaction displayed a high functional group tolerance, and it employed readily available and benchmark stable boronic acid and potassium aryltrifluoroborate derivatives as coupling partners. An appealing late-stage functionalization of indoprofen applying this methodology is showcased.
\end{abstract}

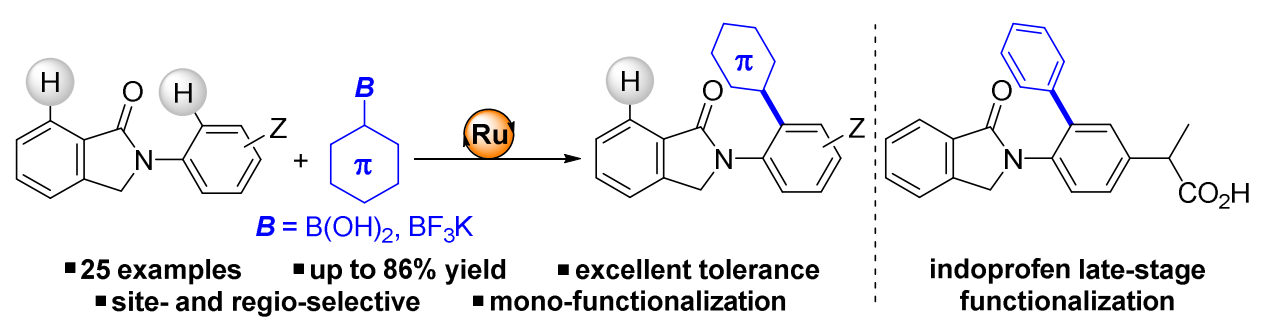




\section{- INTRODUCTION}

Isoindolinones are an important class of compounds which combine a benzene ring fused with a five-membered cyclic tertiary amide. ${ }^{1}$ For instance, $N$-arylisoindolinones are present in many relevant pharmaceutical and medicinal compounds ${ }^{2}$ as well as building blocks for pigments and other molecular materials. ${ }^{3}$ For example, indoprofen (A) displays anti-inflammatory activity, ${ }^{4}$ DWP205190 (B) is known to be an inhibitor for the production of tumor necrosis factor TNF- $\alpha^{5}$ and $\mathbf{C}$ behaves as a potent and selective $5-\mathrm{HT}_{2 \mathrm{C}}$ antagonist (Figure 1 ). ${ }^{6}$ Consequently, the access to molecular diversity arising from the isoindolinone motif is receiving increasing attention. ${ }^{7}$

In particular, the use of weak directing groups in transition metal-catalyzed $\mathrm{C}-\mathrm{H}$ bond functionalization ${ }^{8}$ has emerged as a powerful strategy for implementation in the late-stage derivatization of biologically active molecules in the last years. ${ }^{9}$ In this context, transition metal-catalyzed carbon-carbon bond-forming reactions via $\mathrm{C}-\mathrm{H}$ bond functionalization occupy a central place as they represent a sustainable approach compared to traditional Suzuki, Heck or Stille cross-coupling reactions that generate overstoichiometric amounts of organometallic species starting from highly pre-functionalized building blocks. ${ }^{10}$

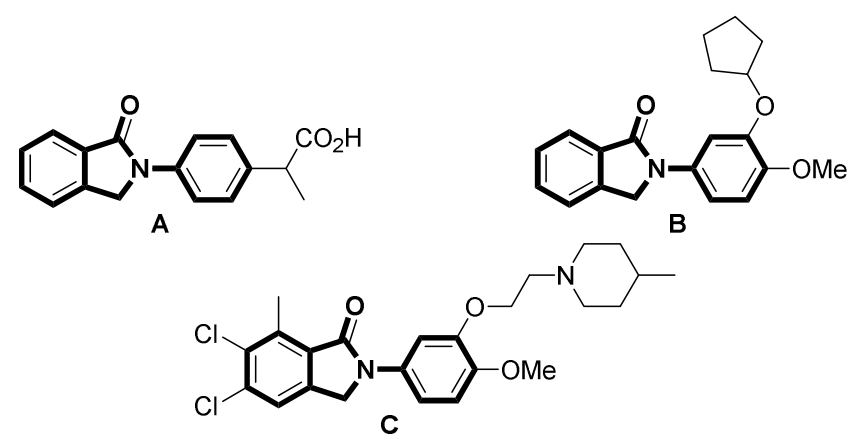

Figure 1. Examples of important $N$-arylisoindolinones.

However, the use of $N$-substituted phenylbenzamides $\left(\mathrm{Ar}^{1}-\mathrm{CONR}-\mathrm{Ar}^{2}\right)$, the acyclic version of $\mathrm{N}$-arylisoindolinones, as weak directing groups for the formation of new carbon-carbon bonds via transition metal-catalyzed $\mathrm{C}-\mathrm{H}$ bond functionalizations remains rare with limited examples reported to date (Figure 2). For instance, Miura and co-workers described a ruthenium-catalyzed hydroarylation of $N, N$-diphenylbenzamide with diphenylacetylene in 2012 (Figure 2A). ${ }^{11}$ Two years later, Glorius and co-workers described an example of rhodium-catalyzed alkynylation of $N$-isopropyl phenylbenzamide with TIPS-EBX (TIPSEBX $=1$ - $[($ triisopropylsilyl)ethynyl $]-1,2$-benziodoxol-3(1H)one) as reagent (Figure $2 \mathrm{~B}$ ) ${ }^{12}$ and a ruthenium-catalyzed cyanation of $N$-methyl phenylbenzamide with NCTS (NCTS $=N$-cyano- $N$-phenyl- $p$-toluenesulfonamide) was developed by Ackermann and co-workers (Figure $2 \mathrm{C}$ ). ${ }^{13}$ In these three examples, ${ }^{11-13}$ the $\mathrm{C}-\mathrm{H}$ bond belonging to the benzamide aromatic ring $\mathrm{A}$ was the one that was functionalized (Figure $2 \mathrm{~A}-\mathrm{C}$ ). These observations highlight the challenge to reverse the site-selectivity for discriminating between two chemically similar aromatic $\mathrm{C}-\mathrm{H}$ bonds where a carbon-carbon bond forming reaction can take place. ${ }^{11-14}$ It is important to note that secondary amides
(RCONHR) behave differently than tertiary amides $\left(\mathrm{RCONR}_{2}\right)$ when transiently coordinating to the metal catalyst throughout the catalytic cycle. Whereas in the former case the nitrogen atom strongly binds to the metal center due to amide tautomerization, ${ }^{15}$ in the latter case it is the oxygen atom that weakly binds to the catalyst. ${ }^{16}$

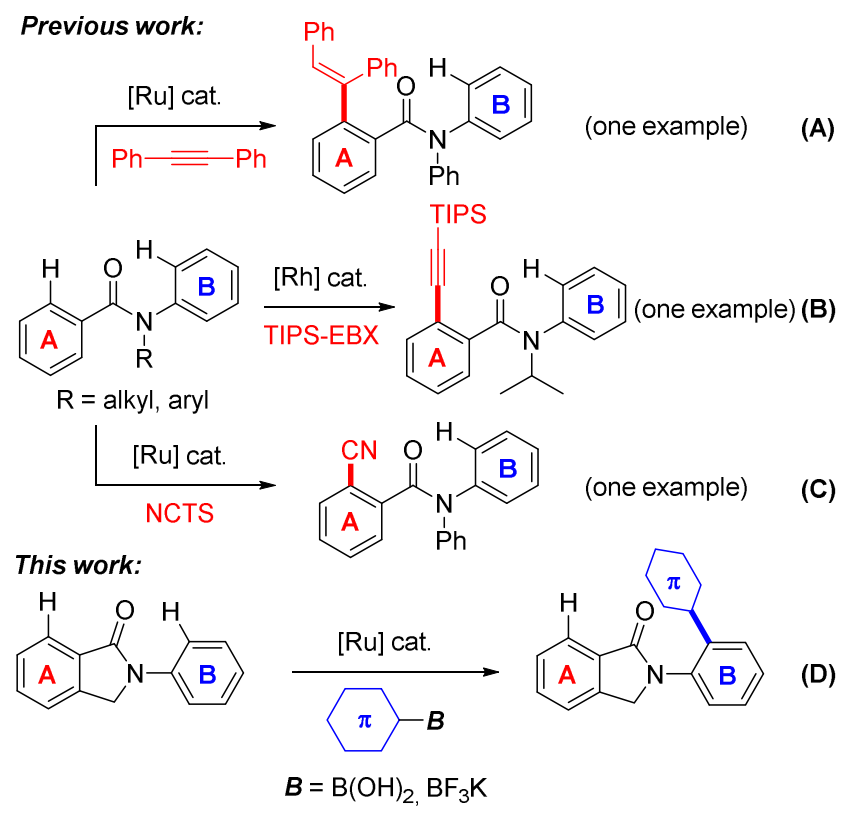

Figure 2. State-of-the-art for the site-selective transition metal-catalyzed carbon-carbon bond formations via aromatic $\mathrm{C}-\mathrm{H}$ bond functionalizations of acyclic $v$ s cyclic $N$ substituted arylbenzamides as weak coordinating groups $(\mathrm{A}-\mathrm{C})$ and present work (D).

In view of the need for methodologies available to target selective $\mathrm{C}-\mathrm{H}$ bond functionalizations with biologically relevant molecules, we report herein on site-selective ruthenium-catalyzed arylation reactions applied to the isoindolinone motif (Figure 2D). The carbonyl group of the cyclic tertiary amide turned out to act as an excellent weak directing group enforcing the catalysis to take place selectively at the ortho position of the acetanilide aromatic ring B employing readily available boronic acid derivatives and potassium aryltrifluoroborates as coupling partners (Figure $2 \mathrm{D}$ ). The methodology was applied to the late-stage derivatization of a biologically relevant target: indoprofen (Figure 1). Selective $\mathrm{C}-\mathrm{H}$ bond arylation reactions occurring in the acetanilide aromatic ring $\mathbf{B}$ of tertiary phenylbenzamides $\left(\mathrm{Ar}^{1}-\mathrm{CONR}-\mathrm{Ar}^{2}\right)$ are unknown to date, although ruthenium-catalyzed $\mathrm{C}-\mathrm{H}$ bond arylations with boronic acid derivatives containing a single aromatic fragment using weak directing groups have been reported. ${ }^{16,17}$

\section{- RESULTS AND DISCUSSION}

Encouraged by the use of aryl boronic acids as coupling partners for ruthenium-catalyzed $\mathrm{C}-\mathrm{H}$ bond arylation of tertiary amides containing a sole aromatic fragment by Szostak and co-workers, ${ }^{16 a} N$-phenylisoindolinone ra was reacted with phenylboronic acid as an aryl source under different reaction conditions in the presence of $\left[\mathrm{RuCl}_{2}(p-\right.$ 
cymene) $]_{2}$ as pre-catalyst to study the formation of arylated products (Table 1 ). Initially, the reaction conditions developed by Szostak were employed leading to $51 \%$ yield of the arylated product $\mathbf{2 a}$, in which the $\mathrm{C}-\mathrm{H}$ bond arylation occurred at the ortho position of the aromatic ring $\mathbf{B}$ (Table 1, entry 1). Gratifyingly, no $\mathrm{C}-\mathrm{H}$ bond arylation occurred in the benzamide aromatic ring $\mathbf{A}$ according to the NMR analyses of the reaction mixture. Whereas the reaction conditions developed by Szostak are sought to proceed via a 5-membered ruthenacycle species, ${ }^{16 a}$ in our case, a 6-membered ruthenacycle species might form considering the outcome of the reaction. In contrast to observations from Szostak, ${ }^{16 a}$ we noticed that the absence of water led to an increase of reactivity with $72 \%$ yield of the targeted compound $2 \mathbf{a}$ (Table 1, entry 2). Changing THF as solvent for 2-MeTHF or NMP led to 2 a in yields as low as $34 \%$ and $10 \%$, respectively (Table 1 , entries 3 and 4 ). The use of DMF, DCE, dioxane, ${ }^{t} \mathrm{AmOH}$, toluene and acetonitrile as solvents, respectively, completely inhibited the reaction (Table 1, entries 5-10). Reactions using different oxidants $\left[\mathrm{Cu}(\mathrm{OAc})_{2} \cdot \mathrm{H}_{2} \mathrm{O},\left(\mathrm{NH}_{4}\right)_{2} \mathrm{~S}_{2} \mathrm{O}_{8}, \mathrm{Ag}_{2} \mathrm{CO}_{3}, \mathrm{AgOAc}\right]$ and triflate metal salts as additives [AgOTf, $\left.\mathrm{Zn}(\mathrm{OTf})_{2}\right]$ in place of $\mathrm{Ag}_{2} \mathrm{O}$ and $\mathrm{Cu}(\mathrm{OTf})_{2}$ led to low yields of the product (Table 1 , entries 11-16). In the presence of one equivalent of $\mathrm{Cu}(\mathrm{OTf})_{2}$ instead of $20 \mathrm{~mol} \%$, the same reactivity was observed (Table 1, entry 17). Other ruthenium complexes such as $\left[\mathrm{Ru}\left(\mathrm{NC}^{t} \mathrm{Bu}\right)_{6}\right]\left(\mathrm{BF}_{4}\right)_{2}$ and $\left[\mathrm{Ru}(p\right.$-cymene $\left.)\left(\mathrm{O}_{2} \mathrm{CMes}\right)_{2}\right]$ were catalytically unproductive (Table 1, entries 18 and 19). These observations suggest that (i) the catalytically active species could involve para-cymene coordinated ruthenium complexes and (ii) the carboxylate anions inhibit the reactions to some extent (see also Table 1, entries 11 and 14). The reaction performed under air atmosphere still afforded $\mathbf{2 a}$ in $55 \%$ yield (Table 1 , entry 20 ). Additionally, control experiments revealed the necessity of all reagents for the favorable outcome of the reaction (Table 1 , entries 21-24). We found that the reaction was also operating at temperatures lower than $110^{\circ} \mathrm{C}$. For instance, $74 \%$ yield of 2a was obtained in a reaction conducted at $90{ }^{\circ} \mathrm{C}$ (Table 1 , entry 25 ), $66 \%$ at $70{ }^{\circ} \mathrm{C}$ (Table 1 , entry 26 ) and $59 \%$ at room temperature (Table 1 , entry 27). This constitutes a unique example of ruthenium-catalyzed $\mathrm{C}-\mathrm{H}$ bond arylation at room temperature and mild conditions using weak directing groups. ${ }^{18}$ We noted that the reaction did not proceed when replacing phenylboronic acid by phenylboronic acid glycol ester (Table 1, entry 28), indicating the preference of this methodology for aryl boronic acids rather than arylboronate derivatives. The catalysis performed at larger scale (starting from $1 \mathrm{mmol}$ of $\mathbf{1 a}$ ) afforded the corresponding product $\mathbf{2 a}$ in $71 \%$ isolated yield (Table 1 , entry 29) using the optimal reaction conditions.
Table 1. Survey for the Optimal Reaction Conditions for the Site-Selective Ru-Catalyzed C-H Bond Arylation of ra with Phenylboronic Acid ${ }^{a}$

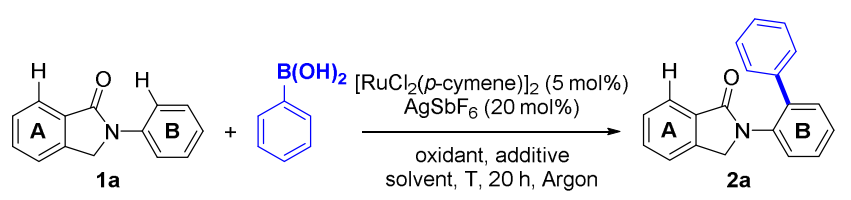

\begin{tabular}{|c|c|c|c|c|c|}
\hline entry & oxidant & additive & solvent & $\begin{array}{c}\mathrm{T} \\
\left({ }^{\circ} \mathrm{C}\right)\end{array}$ & $\begin{array}{l}\text { Yield } \\
(\%)^{b}\end{array}$ \\
\hline $1^{c}$ & $\mathrm{Ag}_{2} \mathrm{O}$ & $\mathrm{Cu}(\mathrm{OTf})_{2}$ & THF & 110 & 51 \\
\hline 2 & $\mathrm{Ag}_{2} \mathrm{O}$ & $\mathrm{Cu}(\mathrm{OTf})_{2}$ & THF & 110 & 72 \\
\hline 3 & $\mathrm{Ag}_{2} \mathrm{O}$ & $\mathrm{Cu}(\mathrm{OTf})_{2}$ & 2-MeTHF & 110 & 34 \\
\hline 4 & $\mathrm{Ag}_{2} \mathrm{O}$ & $\mathrm{Cu}(\mathrm{OTf})_{2}$ & NMP & 110 & 10 \\
\hline 5 & $\mathrm{Ag}_{2} \mathrm{O}$ & $\mathrm{Cu}(\mathrm{OTf})_{2}$ & DMF & 110 & $<5$ \\
\hline 6 & $\mathrm{Ag}_{2} \mathrm{O}$ & $\mathrm{Cu}(\mathrm{OTf})_{2}$ & DCE & 110 & $<5$ \\
\hline 7 & $\mathrm{Ag}_{2} \mathrm{O}$ & $\mathrm{Cu}(\mathrm{OTf})_{2}$ & dioxane & 110 & $<5$ \\
\hline 8 & $\mathrm{Ag}_{2} \mathrm{O}$ & $\mathrm{Cu}(\mathrm{OTf})_{2}$ & ${ }^{t} \mathrm{AmOH}$ & 110 & $<5$ \\
\hline 9 & $\mathrm{Ag}_{2} \mathrm{O}$ & $\mathrm{Cu}(\mathrm{OTf})_{2}$ & toluene & 110 & $<5$ \\
\hline 10 & $\mathrm{Ag}_{2} \mathrm{O}$ & $\mathrm{Cu}(\mathrm{OTf})_{2}$ & $\mathrm{MeCN}$ & 110 & $<5$ \\
\hline 11 & $\mathrm{Cu}(\mathrm{OAc})_{2} \cdot \mathrm{H}_{2} \mathrm{O}$ & $\mathrm{Cu}(\mathrm{OTf})_{2}$ & THF & 110 & o \\
\hline 12 & $\left(\mathrm{NH}_{4}\right)_{2} \mathrm{~S}_{2} \mathrm{O}_{8}$ & $\mathrm{Cu}(\mathrm{OTf})_{2}$ & THF & 110 & o \\
\hline 13 & $\mathrm{Ag}_{2} \mathrm{CO}_{3}$ & $\mathrm{Cu}(\mathrm{OTf})_{2}$ & THF & 110 & 34 \\
\hline 14 & $\mathrm{AgOAc}$ & $\mathrm{Cu}(\mathrm{OTf})_{2}$ & THF & 110 & 9 \\
\hline 15 & $\mathrm{Ag}_{2} \mathrm{O}$ & AgOTf & THF & 110 & o \\
\hline 16 & $\mathrm{Ag}_{2} \mathrm{O}$ & $\mathrm{Zn}(\mathrm{OTf})_{2}$ & THF & 110 & o \\
\hline $17^{d}$ & $\mathrm{Ag}_{2} \mathrm{O}$ & $\mathrm{Cu}(\mathrm{OTf})_{2}$ & THF & 110 & 75 \\
\hline $18^{e}$ & $\mathrm{Ag}_{2} \mathrm{O}$ & $\mathrm{Cu}(\mathrm{OTf})_{2}$ & THF & 110 & o \\
\hline $19^{f}$ & $\mathrm{Ag}_{2} \mathrm{O}$ & $\mathrm{Cu}(\mathrm{OTf})_{2}$ & THF & 110 & o \\
\hline $20^{g}$ & $\mathrm{Ag}_{2} \mathrm{O}$ & $\mathrm{Cu}(\mathrm{OTf})_{2}$ & THF & 110 & 55 \\
\hline $21^{h}$ & $\mathrm{Ag}_{2} \mathrm{O}$ & $\mathrm{Cu}(\mathrm{OTf})_{2}$ & THF & 110 & o \\
\hline $22^{i}$ & $\mathrm{Ag}_{2} \mathrm{O}$ & $\mathrm{Cu}(\mathrm{OTf})_{2}$ & THF & 110 & $<5$ \\
\hline 23 & - & $\mathrm{Cu}(\mathrm{OTf})_{2}$ & THF & 110 & $<5$ \\
\hline 24 & $\mathrm{Ag}_{2} \mathrm{O}$ & - & THF & 110 & 13 \\
\hline 25 & $\mathrm{Ag}_{2} \mathrm{O}$ & $\mathrm{Cu}(\mathrm{OTf})_{2}$ & THF & 90 & $74(72)$ \\
\hline 26 & $\mathrm{Ag}_{2} \mathrm{O}$ & $\mathrm{Cu}(\mathrm{OTf})_{2}$ & THF & 70 & 66 \\
\hline 27 & $\mathrm{Ag}_{2} \mathrm{O}$ & $\mathrm{Cu}(\mathrm{OTf})_{2}$ & THF & 25 & 59 \\
\hline $28^{j}$ & $\mathrm{Ag}_{2} \mathrm{O}$ & $\mathrm{Cu}(\mathrm{OTf})_{2}$ & THF & 110 & $<5$ \\
\hline $29^{k}$ & $\mathrm{Ag}_{2} \mathrm{O}$ & $\mathrm{Cu}(\mathrm{OTf})_{2}$ & THF & 100 & 71 \\
\hline
\end{tabular}

${ }^{a}$ Reaction conditions: 1a (o.1 mmol, 1 equiv.), phenylboronic acid ( 0.25 mmol, 2.5 equiv.), $\left[\mathrm{RuCl}_{2} \text { (p-cymene) }\right]_{2}$ (5 mol\%), $\operatorname{AgSbF}_{6}(20 \mathrm{~mol} \%)$, oxidant (o.1 mmol, 1 equiv.), additive ( $20 \mathrm{~mol} \%$ ), solvent $(0.5 \mathrm{~mL}), 20$ h, Argon. ${ }^{b}$ Determined by ${ }^{1} \mathrm{H}$ NMR spectroscopy analysis using dibromomethane as internal standard; isolated yields obtained after purification by column chromatograph are displayed in parentheses. ${ }^{c} \mathrm{H}_{2} \mathrm{O}$ (3 equiv.). ${ }^{d} \mathrm{Cu}(\mathrm{OTf})_{2}$ (1 equiv.). ${ }^{e}\left[\mathrm{Ru}\left(\mathrm{NC}^{t} \mathrm{Bu}\right)_{6}\right]\left(\mathrm{BF}_{4}\right)_{2}$ instead of $\left[\mathrm{RuCl}_{2}(p \text {-cymene })\right]_{2} . f\left[\mathrm{Ru}(p\right.$-cymene $\left.)\left(\mathrm{O}_{2} \mathrm{CMes}\right)_{2}\right]$ instead of $\left[\mathrm{RuCl}_{2}(p-\right.$ cyme-ne) $]_{2} .{ }^{g}$ Air instead of Argon. ${ }^{h}$ Without $\left[\mathrm{RuCl}_{2}(p \text {-cymene })\right]_{2}$. ${ }^{i}$ Without AgSbF 6 . ${ }^{j}$ Phenylboronic acid glycol ester instead of phenylboronic acid. ${ }^{k}$ Reaction conditions: $1 \mathbf{a}(1 \mathrm{mmol}, 1$ equiv.), phenylboronic acid (2.5 mmol, 2.5 equiv.), $\left[\mathrm{RuCl}_{2}(p \text {-cymene) }]_{2}\right.$ (5 mol\%), $\mathrm{AgSbF}_{6}(20 \mathrm{~mol} \%), \mathrm{Ag}_{2} \mathrm{O}$ (1 mmol, 1 equiv.), $\mathrm{Cu}(\mathrm{OTf})_{2}(20 \mathrm{~mol} \%)$, THF $(5 \mathrm{~mL}), 2 \mathrm{o} \mathrm{h}$, Argon.

Next, we applied the optimal reaction conditions we found (Table 1 , entry 25 ) to $N$-arylisoindolinones 1 and boronic acid derivatives containing both different substitution patterns in order to determine the scope and limitations for this transformation (Table 2). Isoindolinones 
para-substituted with methyl, methoxy and chloro groups were well tolerated leading to the corresponding arylated products 2b-2d in 6o-86\% yield. Notably, carboxylic acid ester groups were suitable for the ruthenium-catalyzed C$\mathrm{H}$ bond arylation protocol affording $2 \mathbf{e}$ in $55 \%$ yield. Although ester groups are known to direct some rutheniumcatalyzed $\mathrm{C}-\mathrm{H}$ bond functionalizations, ${ }^{19}$ in the present case the isoindolinone core seems to be more appropriate for coordination to ruthenium and thus, it exclusively dictates the selectivity of the reaction. Unfortunately, nitrilecontaining partners are not compatible with the catalysis (2f) as it appeared to be the case in other ruthenium-catalyzed $\mathrm{C}-\mathrm{H}$ bond functionalizations as well..$^{15-17}$ Dioxolanecontaining isoindolinone led to a single isomer $2 \mathrm{~g}$ in $40 \%$ isolated yield. Methyl- and methoxy-substituted isoindolinones in meta position led exclusively to $\mathbf{2 h}$ and $\mathbf{2 i}$, respectively, in 55\% and 59\% yield. Moreover, the reactions were sensitive to the steric hindrance found in some substrates. For instance, ortho-substituted coupling partners did not react as evidenced in the absence of formation of 2j-2k. However, the reaction did operate using orthofluorophenylboronic acid and ortho-methoxyphenylboronic acid as coupling partners leading to $\mathbf{2 l}$ and $\mathbf{2 m}$ in $55 \%$ and $44 \%$ yield, respectively. meta-Substituted phenylboronic acids are overall well tolerated with the only exception of the chloride derivative, which led to $2 \mathrm{n}$ in $15 \%$ yield. On the other hand, the reactions with methyl-, methoxy- and nitro-containing boronic acids afforded the corresponding products $\mathbf{2 0}, \mathbf{2 p}$ and $\mathbf{2 q}$ in $74 \%, 32 \%$ and $60 \%$ yields, respectively. As such, the reaction seems to be sensitive to the electronic effects imposed by the boronic acids substituted in meta position. The reaction for 3,5-dimethylphenylboronic acid gave rise to the corresponding arylated product $\mathbf{2 r}$ in $70 \%$ yield. para-Substituted phenylboronic acids were also used in this $\mathrm{C}-\mathrm{H}$ bond arylation protocol. Methyl- and methoxy-containing products $2 \mathbf{s}$ and $\mathbf{2 t}$ were formed in comparable yields of $77 \%$ and $79 \%$. In the case of reactions with substrates containing halides in the para position of the phenylboronic acid, a trend was observed following the order of reactivity $\mathrm{F}<\mathrm{Cl}<\mathrm{Br}$ with $\mathbf{2 u}, \mathbf{2 V}$ and $\mathbf{2 w}$ respectively obtained in $19 \%, 55 \%$ and $81 \%$ yield. The main by-product observed during the formation of $\mathbf{2 u}$ is the one resulting from the homocoupling of the corresponding boronic acid derivative. Naphthalene-containing boronic acids efficiently reacted leading to $\mathbf{2 x}$ and 2y in $83 \%$ and $70 \%$ yield, respectively. The reaction with very bulky 1-naphthaleneboronic acid still afforded the corresponding product $\mathbf{2 z}$ but in a low yield of $10 \%$.

Moreover, single crystal X-ray diffraction studies established the molecular structures of $\mathbf{2 c}, \mathbf{2 d}, \mathbf{2 g}, \mathbf{2 m}, \mathbf{2 n}$ and 20 (Table 2 ), thus unambiguously supporting the control of the site- and regio-selectivity during the catalysis. It is worthy to mention that the traditional synthetic route towards this types of products require the use of over-stoichiometric amounts of metal zinc and highly pre-functionalized starting materials, which require an important number of additional steps that significantly decreases the overall yield and generates significant chemical waste. ${ }^{\mathbf{2 o a}}$ As such, the presented ruthenium-catalyzed arylation is appealing in terms of an atom- and step-economy methodology. Importantly, analogs to products 2 have been studied against the spinal muscular atrophy. ${ }^{20 b}$
Table 2. Scope and Limitations for the C-H Bond Arylation of $\mathrm{N}$-arylisoindolinones ${ }^{a}$
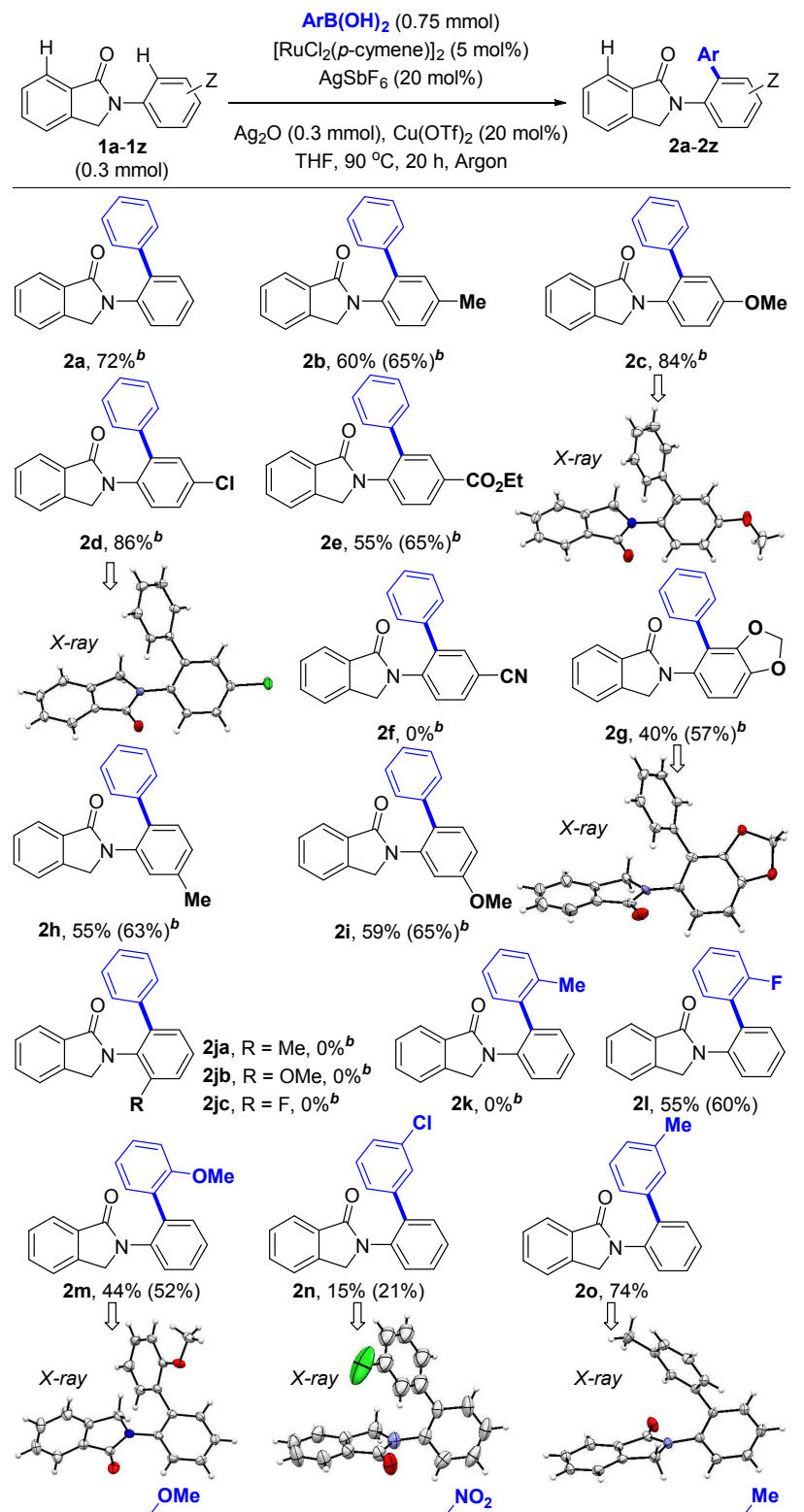

$21,55 \%(60 \%)$
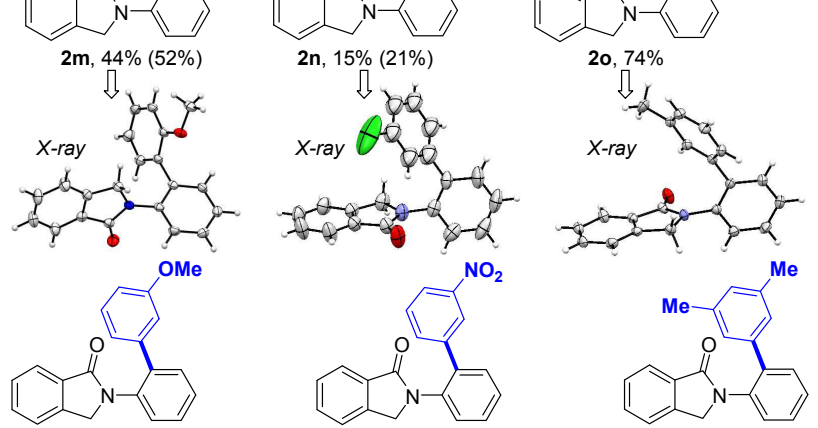

2p, $32 \%(40 \%)$

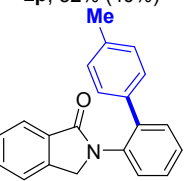

2q, $60 \%(67 \%)$
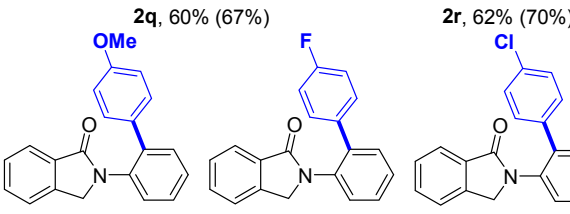

2s, $77 \%$

2t, $79 \%$

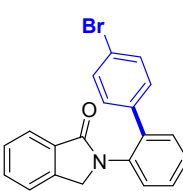

2w, $81 \%$

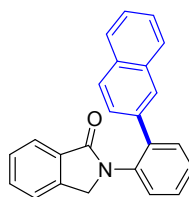

$2 x, 83 \%$

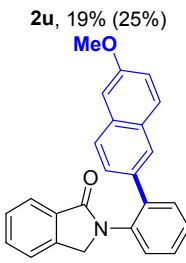

$2 y, 70 \%$

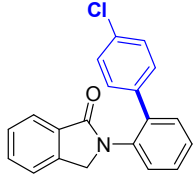

$2 v, 55 \%(61 \%)$

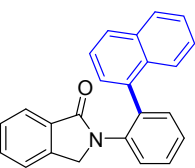

$2 \mathbf{z}, 10 \%(15 \%)$

${ }^{a}$ Isolated yields obtained after purification by column chromatography are displayed whereas conversions are shown in parentheses. ${ }^{b} 110{ }^{\circ} \mathrm{C}$ instead of $90{ }^{\circ} \mathrm{C}$. 
Interestingly, no $\mathrm{C}-\mathrm{H}$ bond bis-arylation was observed for any of the cases presented in Table 2. In some cases, the product resulting from the homocoupling of the boronic acid derivative was detected as illustrated by the isolation of $\mathbf{3}$ (vide infra) during the purification of $\mathbf{2 n}$. This homocoupling reaction appears to be a side reaction that may explain the relatively low yields obtained in some of the cases in Table 2 . We noted that very challenging boronic acids such as alkyl boronic ones (e.g. 1-butylboronic acid) and heteroaromatic-containing ones (e.g. 3-thiopheneboronic acid) did not react under the studied reaction conditions illustrating the current limitations of the methodology as it has been shown before with other substrates. ${ }^{16 a, 17}$

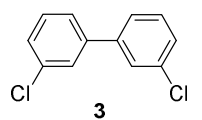

In order to study the relevance of the carbonyl group from the isoindolinone core as a weak directing group in the catalysis, we performed a control reaction employing a substrate featuring no ketone group. Under the studied reaction conditions, isoindoline $\mathbf{4}$ did no afford any arylated product (Eq. 1). The same outcome was observed in the catalysis with the cyclic imides $\mathbf{5}$ and $\mathbf{6}$ as substrates (Eq. $\mathbf{2}$ and Eq. 3). These findings suggest that (i) the carbonyl group of the isoindolinone $\mathbf{1}$ acts as a weak directing unit throughout the catalytic cycle and (ii) that the flexibility and less steric hindrance of cyclic amides (i.e. 1) when compared to cyclic imides (i.e. 5-6) enable to accommodate key ruthenacycle species. Deuteration experiments using $N$-phenylisoindolinone ra were performed and they were not conclusive at this stage.
(1)

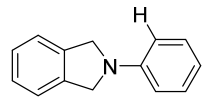

4 (0.3 mmol)

(2)

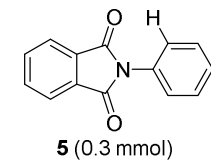

(3)

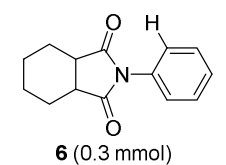

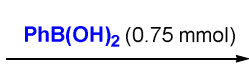

As Table 4

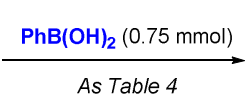

$\mathrm{PhB}(\mathrm{OH})_{2}(0.75 \mathrm{mmol})$

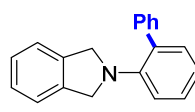

$0 \%$
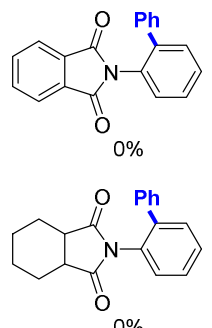

These data, combined with previous observations, ${ }^{16 a, 17,21}$ enabled us to suggest a plausible reaction mechanism for the C-H bond arylation of $\mathrm{N}$-arylisoindolinones (Scheme 1). Initially, chloride-free ruthenium(II) complexes coordinate to substrate $\mathbf{l}$ via the oxygen lone pair of the ketone group to from species I. Then, base-assisted C-H bond activation enabled by triflate anions led to a six-membered ruthenacycle species II. In the presence of boronic acids, intermediate III forms that undergoes reductive elimination giving product $\mathbf{2}$ and the resulting ruthenium(o) species were regenerated into active ruthenium(II) species upon oxidation with $\mathrm{Ag}_{2} \mathrm{O}$.
Scheme 1. Simplified, Plausible Catalytic Cycle for the Ru-Catalyzed C-H Bond Arylation of Isoindolinones 1

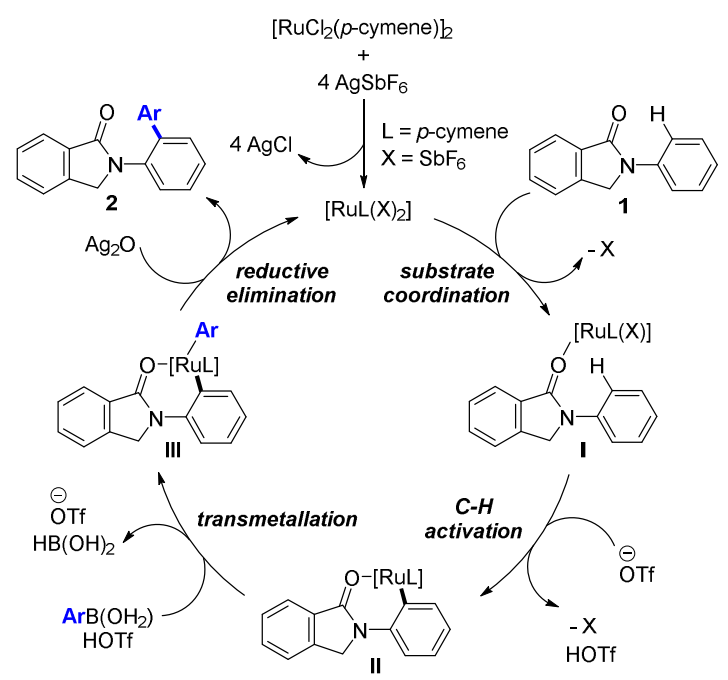

To further demonstrate the potential and utility of this methodology, we decided to apply it to the late-stage functionalization of biologically relevant indoprofen $\mathbf{A}$ (Figure 1 and Scheme 2), which is known to display anti-inflammatory activity. ${ }^{4}$ Indoprofen A contains a carboxylic acid that, unfortunately, is not compatible under the standard reaction conditions. However, it can readily be converted into an ester group, which in turn, is compatible with our methodology (see ze in Table 2). Consequently, we performed a reaction sequence involving (1) esterification, (2) ruthenium-catalyzed $\mathrm{C}-\mathrm{H}$ bond arylation and (3) ester hydrolysis. In this manner, the corresponding ortho-arylated indoprofen 7 was obtained in $76 \%$ overall yield starting from indoprofen over three steps (Scheme 2). The regioand site-selectivity observed in the resulting product 7 was determined by multinuclear NMR spectroscopy studies. During the sequence, only one column chromatography was performed in the second step as the first and third steps are almost quantitative and require a trivial acid/base workup for the isolation of the products. As such, this sequence can be considered as sustainable to some extent.

Scheme 2. Application of the Ru-Catalyzed Site-Selective C-H Bond Arylation to the Late-Stage Functionalization of Indoprofen ${ }^{a}$

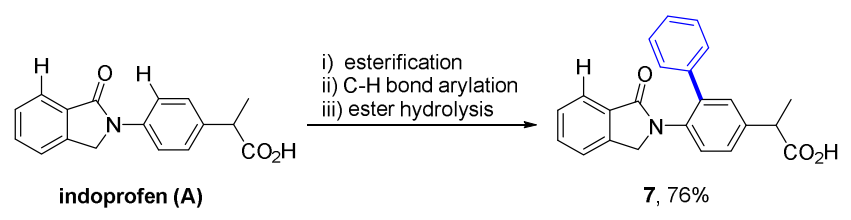

${ }^{a}$ Reaction conditions: (i) $\mathrm{H}_{2} \mathrm{SO}_{4}$ (cat.), EtOH, reflux, $12 \mathrm{~h}, 99 \%$; (ii) $\mathrm{Ph}(\mathrm{BOH})_{2}$ (2.5 equiv.), $\left[\mathrm{RuCl}_{2}(p \text {-cymene })\right]_{2}$ (5 mol\%), $\mathrm{AgSbF}_{6}(20$ $\mathrm{mol} \%), \mathrm{Ag}_{2} \mathrm{O}$ (1 equiv.), $\mathrm{Cu}(\mathrm{OTf})_{2}$ (20 mol\%), THF, $90{ }^{\circ} \mathrm{C}, 20 \mathrm{~h}, 85 \%$; (iii) $\mathrm{NaOH}$ (2 M), MeOH:THF, r.t., 12 h, 9o\%. 
In addition, we reasoned that potassium organotrifluoroborates, which are nowadays well recognized as efficient coupling partners in cross-coupling chemistry, ${ }^{22}$ may eventually be used for site-selective ruthenium-catalyzed $\mathrm{C}-\mathrm{H}$ bond arylation reactions as well. As a proof of concept, $N$-phenylisoindolinone ra was submitted to our standard reaction conditions but employing potassium phenyltrifluoroborate as the aryl source for the $\mathrm{C}-\mathrm{H}$ bond functionalization instead of phenylboronic acid. Gratifyingly, the reaction was equally efficient leading to the mono-arylated product $\mathbf{2 a}$ in $68 \%$ yield (Eq. 4 ).

(4)

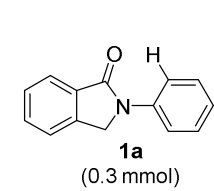

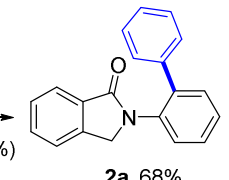

2a, $68 \%$

Finally, for comparison purposes, $N$-phenylisoindolinone 1a was submitted to the reaction conditions traditionally used for ruthenium-catalyzed $\mathrm{C}-\mathrm{H}$ bond arylation reactions with strong nitrogen-containing directing units. ${ }^{23}$ They consist of $\left[\mathrm{RuCl}_{2}(p \text {-cymene })\right]_{2}$ (5 mol\%), KOAc (20 mol\%), $\mathrm{K}_{2} \mathrm{CO}_{3}$ as base, bromobenzene as aryl source in NMP as solvent at $150{ }^{\circ} \mathrm{C}$ (Eq. 5). Under these reaction conditions, the starting material la was found unreactive. This shows the true potential of boronic acids and related derivatives ${ }^{17}$ as an alternative to replace aryl halides and aryl pseudo-halides as coupling partners for challenging $\mathrm{C}-\mathrm{H}$ bond arylation reactions with transition metal catalysts, as it is the case here for weak directing groups.

(5)

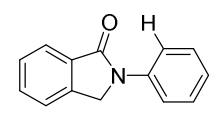

$1 \mathrm{a}(0.1 \mathrm{mmol})$
$\operatorname{PhBr}(1.25$ equiv.)

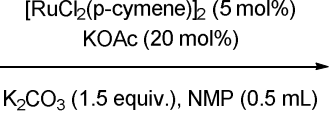

$150^{\circ} \mathrm{C}, 24 \mathrm{~h}$, Argon

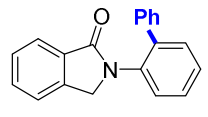

$0 \%$
Furthermore, the same reaction conditions applied to $N$-phenylphthalimide 5 did not produce any arylated product, but $N$-phenylbenzamide was formed to some extent (Eq. 6). We have previously reported improved reaction conditions, and substrate scope and limitations regarding this unexpected ruthenium-catalyzed protodecarbonylation reaction. ${ }^{24}$
(6)

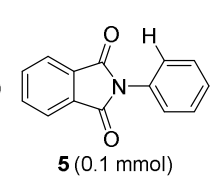

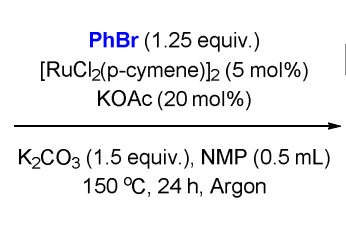

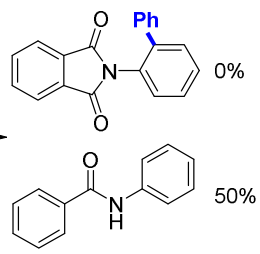

\section{- CONCLUSIONS}

In conclusion, we have disclosed an efficient and site-selective ruthenium-catalyzed $\mathrm{C}-\mathrm{H}$ bond arylation protocol to form unique aromatic $\mathrm{C}\left(\mathrm{sp}^{2}\right)-\mathrm{C}\left(\mathrm{sp}^{2}\right)$ bonds within the biologically relevant isoindolinone skeleton. A large number of number of useful functional chemical groups [e.g. fluoro, chloro, bromo, nitro, alkyl, (a)cyclic ethers, esters, polycyclic aromatic hydrocarbons] at different positions (ortho, meta, para) within the different coupling partners are tolerated by the catalysis due to the mild conditions employed. This catalysis represents a type of general selective functionalization in which combining a ruthenium(II) catalyst with a weak coordinating group (i.e. cyclic amide) promotes the discrimination of one out of two aromatic C$\mathrm{H}$ bonds with similar bond dissociation energies. In addition, mono-arylated products were exclusively obtained in the above-described catalysis. The previously neglected homocoupling side-products observed during the $\mathrm{C}-\mathrm{H}$ bond arylation reaction are likely originating from a simultaneous reaction that competes with the $\mathrm{C}-\mathrm{H}$ bond arylation. Importantly, this methodology shows the relevance of ruthenium(II) pre-catalysts leading to the formation of six-membered ruthenacycles during the catalysis even when using weak coordinating groups within the substrate. In addition, and considering the availability of the developed ruthenium-based catalytic systems, one could expect manifold implementations of this strategy in the late-stage derivatization of potential drug candidates (as it is shown here with indoprofen) and (supra)molecular materials that feature such relevant organic skeleton or similar chemical motifs.

\section{- EXPERIMENTAL SECTION}

General Methods. All reagents were obtained from commercial sources and used as supplied. All reactions were carried out in flame-dried glassware under argon atmosphere unless otherwise noted. Catalytic experiments were performed in Schlenk-type flasks under argon atmosphere unless otherwise noted. Organic solutions were concentrated under reduced pressure using a rotary evaporator. Thin-layer chromatography (TLC) were carried out on 0.25 mm Merck silica gel (6o-F254). Flash column chromatography was performed using silica gel Silica $60 \mathrm{M}$, o.04$0.063 \mathrm{~mm}$. Technical grade petroleum ether (40-6o), nheptane and ethyl acetate were used for column chromatography. $\mathrm{CDCl}_{3}$ was stored under nitrogen over molecular sieves. NMR spectra were recorded on an AVANCE III 400 spectrometer. ${ }^{1} \mathrm{H}$ NMR spectra were referenced to residual protiated solvent ( $\delta=7.26 \mathrm{ppm}$ for $\mathrm{CDCl}_{3}, \delta=2.50 \mathrm{ppm}$ for DMSO- $d_{6}$ and $\delta=2.05$ ppm for acetone- $d_{6}$ ) and ${ }^{13} \mathrm{C}$ chemical shifts are reported relative to deuterated solvents $(\delta=$ 77.0 ppm for $\mathrm{CDCl}_{3}, \delta=39.5 \mathrm{ppm}$ for DMSO- $d_{6}$ and $\delta=$ $29.8 \mathrm{ppm}$ for acetone- $d_{6}$ ) [Note: acetone- $d_{6}$ contains traces of water at $c a .3 \mathrm{ppm}$ ]. The peak patterns are indicated as follows: s, singlet; d, doublet; $t$, triplet; q, quartet; m, multiplet, and br. for broad. GC-MS analyses were performed with a GCMS-QP2010S (Shimadzu) instrument with a GC2010 equipped with a $30 \mathrm{~m}$ capillary column (Supelco, SLBTM-5ms, fused silica capillary column, $30 \mathrm{~m} \times 0.25 \mathrm{~mm}$ $\mathrm{x} 0.25 \mathrm{~mm}$ film thickness), which was used with helium as the vector gas. The following GC conditions were used: initial temperature $80^{\circ} \mathrm{C}$ for 2 minutes, then $20{ }^{\circ} \mathrm{C} / \mathrm{min}$ until $280^{\circ} \mathrm{C}$ and $280^{\circ} \mathrm{C}$ for 28 minutes. HRMS were recorded on a Waters Q-Tof 2 mass spectrometer at the corresponding facilities of the CRMPO, Centre Régional de Mesures Physiques de l'Ouest, Université de Rennes 1. 
Synthesis and characterization of $\mathrm{N}$-arylisoindolinone substrates (1): A mixture of 2-formylbenzoic acid (o.751 $\mathrm{g}, 5 \mathrm{mmol}, 1$ equiv.), the corresponding aniline derivative ( $6 \mathrm{mmol}, 1.2$ equiv.), DABCO ( $1.122 \mathrm{~g}, 10 \mathrm{mmol}, 2$ equiv.), $\mathrm{HCOOH}$ (1.25 mL, $1.525 \mathrm{~g}, 33.1 \mathrm{mmol}), \mathrm{Pd}(\mathrm{OAc})_{2}$ (0.056 g, $0.25 \mathrm{mmol}, 5 \mathrm{~mol} \%$ ) in 1,4-dioxane $(5 \mathrm{~mL}$ ) was heated in an oil bath at $80^{\circ} \mathrm{C}$ for 3 hours. After completion of the reaction, the mixture was cooled to room temperature, and diluted with DCM $(50 \mathrm{~mL})$. The solid was removed by filtration, and the filtrate was washed with water $(50 \mathrm{~mL})$ and brine $(50 \mathrm{~mL})$. The organic layer was dried over $\mathrm{Na}_{2} \mathrm{SO}_{4}$, filtered, and concentrated under reduced pressure. The residue was purified by column chromatography on silica gel (petroleum ether/acetone $=5 / 1, v / v$ ) to afford the desired product $\mathbf{1}$.

2-Phenylisoindolin-1-one (1a): starting from aniline (o.55 mL, 0.559 g, $6 \mathrm{mmol}$ ) in 98\% isolated yield (1.03 g). ${ }^{1} \mathrm{H}$ NMR (400 $\mathrm{MHz}, \mathrm{CDCl}_{3}$ ): $\delta=7.93\left(\mathrm{~d}, J=7.6 \mathrm{~Hz},{ }_{1} \mathrm{H}\right)$, 7.89-7.86 (m, 2H), 7.62-7.58 (m, $1 \mathrm{H}), 7.53-7.49(\mathrm{~m}, 2 \mathrm{H})$, $7.43(\mathrm{dd}, J=8.4,7.2 \mathrm{~Hz}, 2 \mathrm{H}), 7.18(\mathrm{dd}, J=7.2,7.2 \mathrm{~Hz}, 1 \mathrm{H})$, $4.87(\mathrm{~s}, 2 \mathrm{H}) \mathrm{ppm}$. The spectral data match those previously reported. 25

2-(p-Tolyl)isoindolin-1-one (1b): starting from $p$-toluidine (o.66 mL, o.643 g, $6 \mathrm{mmol}$ ) in $80 \%$ isolated yield (o.89 g). ${ }^{1} \mathrm{H}$ NMR (40o $\left.\mathrm{MHz}, \mathrm{CDCl}_{3}\right): \delta=7.92\left(\mathrm{~d}, J=7.2 \mathrm{~Hz},{ }_{1} \mathrm{H}\right)$, $7.74(\mathrm{~d}, J=8.4 \mathrm{~Hz}, 2 \mathrm{H}), 7.59\left(\mathrm{dd}, J=7.6,7.6 \mathrm{~Hz},{ }_{1} \mathrm{H}\right), 7.5 \mathrm{O}$ $(\mathrm{dd}, J=6.8,6.8 \mathrm{~Hz}, 2 \mathrm{H}), 7.24(\mathrm{~d}, J=8.4 \mathrm{~Hz}, 2 \mathrm{H}), 4.84$ (s, $2 \mathrm{H}), 2.36(\mathrm{~s}, 3 \mathrm{H}) \mathrm{ppm}$. The spectral data match those previously reported. ${ }^{25}$

2-(p-Methoxyphenyl)isoindolin-1-one (1c): starting from $p$-anisidine $(0.739 \mathrm{~g}, 6 \mathrm{mmol})$ in $62 \%$ isolated yield (o.74 g). ${ }^{1} \mathrm{H} \mathrm{NMR}\left(400 \mathrm{MHz}, \mathrm{CDCl}_{3}\right): \delta=7.92(\mathrm{~d}, J=7.6 \mathrm{~Hz}$, $1 \mathrm{H}), 7.74(\mathrm{~d}, J=9.2 \mathrm{~Hz}, 2 \mathrm{H}), 7.58(\mathrm{dd}, J=7.6,7.6 \mathrm{~Hz}, 1 \mathrm{H})$, $7.52-7.48(\mathrm{~m}, 2 \mathrm{H}), 6.97(\mathrm{~d}, J=9.2 \mathrm{~Hz}, 2 \mathrm{H}), 4.83(\mathrm{~s}, 2 \mathrm{H}), 3.83$ $(\mathrm{s}, 3 \mathrm{H}) \mathrm{ppm}$. The spectral data match those previously reported. 25

2-(p-Chlorophenyl)isoindolin-1-one (1d): starting from $p$-chloroaniline $(0.765 \mathrm{~g}, 6 \mathrm{mmol})$ in $61 \%$ isolated yield (o.74 g). ${ }^{1} \mathrm{H}$ NMR (40o MHz, $\left.\mathrm{CDCl}_{3}\right): \delta=7.92(\mathrm{~d}, J=7.2 \mathrm{~Hz}$, $1 \mathrm{H}), 7.74(\mathrm{dd}, J=9.2,2.4 \mathrm{~Hz}, 2 \mathrm{H}), 7.61$ (ddd, $J=7.6,7.6,1.2$ $\mathrm{Hz}, 1 \mathrm{H}), 7.54-7.50(\mathrm{~m}, 2 \mathrm{H}), 7.39$ (dd, $J=9.2,2.4 \mathrm{~Hz}, 2 \mathrm{H})$, $4.84(\mathrm{~s}, 2 \mathrm{H}) \mathrm{ppm}$. The spectral data match those previously reported. ${ }^{25}$

Ethyl 4-(1-oxoisoindolin-2-yl)benzoate (1e): starting from ethyl 4-aminobenzoate (0.991 g, $6 \mathrm{mmol})$ in $96 \%$ isolated yield (1.35 g). ${ }^{1} \mathrm{H}$ NMR (40o $\mathrm{MHz}, \mathrm{CDCl}_{3}$ ): $\delta=8.11$ (d, $J=8.4 \mathrm{~Hz}, 2 \mathrm{H}), 7.99(\mathrm{~d}, J=8.8 \mathrm{~Hz}, 2 \mathrm{H}), 7.94(\mathrm{~d}, J=7.6 \mathrm{~Hz}$, $1 \mathrm{H}), 7.63(\mathrm{dd}, J=7.6,7.6 \mathrm{~Hz}, 1 \mathrm{H}), 7.53(\mathrm{dd}, J=7.6,7.6 \mathrm{~Hz}$, $2 \mathrm{H}), 4.90(\mathrm{~s}, 2 \mathrm{H}), 4.39(\mathrm{q}, J=7.2 \mathrm{~Hz}, 2 \mathrm{H}), 1.41(\mathrm{t}, J=7.2 \mathrm{~Hz}$, $\left.{ }_{3} \mathrm{H}\right)$ ppm. The spectral data match those previously reported. ${ }^{25}$

4-(1-Oxoisoindolin-2-yl)benzonitrile (1f): starting from 4 -aminobenzonitrile ( $0.709 \mathrm{~g}, 6 \mathrm{mmol})$ in $64 \%$ isolated yield (o.71 g). ${ }^{1} \mathrm{H}$ NMR (40o $\left.\mathrm{MHz}, \mathrm{CDCl}_{3}\right): \delta=8.06(\mathrm{~d}, J=$ $9.2 \mathrm{~Hz}, 2 \mathrm{H}), 7.94(\mathrm{~d}, J=7.2 \mathrm{~Hz}, 1 \mathrm{H}), 7.71(\mathrm{~d}, J=8.8 \mathrm{~Hz}, 2 \mathrm{H})$, $7.65(\mathrm{dd}, J=7.6,7.2 \mathrm{~Hz}, 1 \mathrm{H}), 7.54(\mathrm{dd}, J=7.6,7.2 \mathrm{~Hz}, 2 \mathrm{H})$, $4.89(\mathrm{~s}, 2 \mathrm{H}) \mathrm{ppm}$. The spectral data match those previously reported. 25

2-(Benzo $[d][1,3]$ dioxol-5-yl)isoindolin-1-one (1g): starting from 3,4-(methylenedioxy)aniline (o.823 g, 6 $\mathrm{mmol}$ ) in $58 \%$ isolated yield (o.73 g). ${ }^{1} \mathrm{H} \mathrm{NMR} \mathrm{(400} \mathrm{MHz,}$ $\left.\mathrm{CDCl}_{3}\right): \delta=7.92(\mathrm{~d}, J=8.0 \mathrm{~Hz}, 1 \mathrm{H}), 7.61-7.57(\mathrm{~m}, 2 \mathrm{H}), 7.51$ (dd, $J=6.4,5.6 \mathrm{~Hz}, 2 \mathrm{H}$ ), $7.11(\mathrm{dd}, J=8.4,2.0 \mathrm{~Hz}, 1 \mathrm{H}), 6.85$ $(\mathrm{d}, J=8.4 \mathrm{~Hz}, 1 \mathrm{H}), 5.99(\mathrm{~s}, 2 \mathrm{H}), 4.81(\mathrm{~s}, 2 \mathrm{H}) \mathrm{ppm}$. The spectral data match those previously reported. ${ }^{25}$

2-(m-Tolyl)isoindolin-1-one (1h): starting from $m$-toluidine (o.64 mL, o.643 g, $6 \mathrm{mmol}$ ) in 65\% isolated yield (o.73 g). ${ }^{1} \mathrm{H}$ NMR $\left(400 \mathrm{MHz}, \mathrm{CDCl}_{3}\right): \delta=7.93\left(\mathrm{~d}, J=6.8 \mathrm{~Hz},{ }_{1} \mathrm{H}\right)$, $7.73(\mathrm{~s}, 1 \mathrm{H}), 7.65-7.58(\mathrm{~m}, 2 \mathrm{H}), 7.51(\mathrm{dd}, J=7.2,6.8 \mathrm{~Hz}, 2 \mathrm{H})$, $7.32(\mathrm{dd}, J=8.0,8.0 \mathrm{~Hz}, 1 \mathrm{H}), 7.01(\mathrm{~d}, J=7.6 \mathrm{~Hz}, 1 \mathrm{H}), 4.86$ $(\mathrm{s}, 2 \mathrm{H}), 2.41(\mathrm{~s}, 3 \mathrm{H}) \mathrm{ppm}$. The spectral data match those previously reported. ${ }^{25}$

2-(m-Methoxyphenyl)isoindolin-1-one (1i): starting from $\mathrm{m}$-anisidine (o.67 mL, $0.739 \mathrm{~g}, 6 \mathrm{mmol}$ ) in $80 \%$ isolated yield (o.96 g). ${ }^{1} \mathrm{H}$ NMR (40o $\left.\mathrm{MHz}, \mathrm{CDCl}_{3}\right): \delta=7.93(\mathrm{~d}$, $\left.J=7.2 \mathrm{~Hz},{ }_{1 \mathrm{H}}\right), 7.69(\mathrm{dd}, J=2.0,1.6 \mathrm{~Hz}, 1 \mathrm{H}), 7.62-7.58(\mathrm{~m}$, $1 \mathrm{H}), 7.51(\mathrm{dd}, J=7.6,7.6 \mathrm{~Hz}, 2 \mathrm{H}), 7.34-7.32(\mathrm{~m}, 2 \mathrm{H}), 6.76-$ $6.73(\mathrm{~m}, 1 \mathrm{H}), 4.86(\mathrm{~s}, 2 \mathrm{H}), 3.87(\mathrm{~s}, 3 \mathrm{H}) \mathrm{ppm}$. The spectral data match those previously reported. ${ }^{25}$

2-(o-Tolyl)isoindolin-1-one (1ja): starting from o-toluidine (o.64 mL, o.643 g, $6 \mathrm{mmol}$ ) in 68\% isolated yield (o.76 g). ${ }^{1} \mathrm{H}$ NMR $\left(400 \mathrm{MHz}, \mathrm{CDCl}_{3}\right): \delta=7.96\left(\mathrm{~d}, J=7.6 \mathrm{~Hz},{ }_{1} \mathrm{H}\right)$, 7.61 (ddd, $J=7.2,7.2,1.2 \mathrm{~Hz}, 1 \mathrm{H}), 7.55^{-7.50}(\mathrm{~m}, 2 \mathrm{H}), 7.35^{-}$ $7.32(\mathrm{~m}, 1 \mathrm{H}), 7 \cdot 30-7.24(\mathrm{~m}, 3 \mathrm{H}), 4.74(\mathrm{~s}, 2 \mathrm{H}), 2.27\left(\mathrm{~s},{ }_{3} \mathrm{H}\right)$ $\mathrm{ppm}$. The spectral data match those previously reported. ${ }^{25}$

2-(2-Methoxyphenyl)isoindolin-1-one (1jb): starting from o-anisidine (X.XX mL, X.XX g, X mmol) in 61\% isolated yield (X.XX g). ${ }^{1} \mathrm{H}$ NMR (40o $\mathrm{MHz}, \mathrm{CDCl}_{3}$ ): $\delta=7.94$ $(\mathrm{d}, J=7.6 \mathrm{~Hz}, 1 \mathrm{H}), 7.58$ (ddd, $J=7.2,7.2,1.2 \mathrm{~Hz}, 1 \mathrm{H}), 7.49$ (dd, $J=7.6,7.2 \mathrm{~Hz}, 2 \mathrm{H}$ ), 7.43 (dd, $J=8.0,1.6 \mathrm{~Hz}, 1 \mathrm{H}), 7.32$ (ddd, $J=8.0,8.0,1.2 \mathrm{~Hz}, 1 \mathrm{H})$, 7.06-7.0o (m, $2 \mathrm{H}), 4.80$ (s, $2 \mathrm{H}), 3.82(\mathrm{~s}, 3 \mathrm{H})$ ppm.. The spectral data match those previously reported. ${ }^{25}$

2-(2-Fluorophenyl)isoindolin-1-one (1jc): starting from o-fluoroaniline (o.19 mL, $0.222 \mathrm{~g}, 2 \mathrm{mmol})$ in $76 \%$ isolated yield (o.35 g). ${ }^{1} \mathrm{H}$ NMR (400 $\left.\mathrm{MHz}, \mathrm{CDCl}_{3}\right): \delta=7.97(\mathrm{~d}, J=$ 7.4 Hz, $1 \mathrm{H}), 7.67-7.60(\mathrm{~m}, 2 \mathrm{H}), 7.52(\mathrm{t}, J=7.5 \mathrm{~Hz}, 2 \mathrm{H}), 7.33^{-}$ $7.27(\mathrm{~m}, 1 \mathrm{H}), 7.25-7.18(\mathrm{~m}, 2 \mathrm{H}), 4.88(\mathrm{~s}, 2 \mathrm{H}) \mathrm{ppm} .{ }^{19} \mathrm{~F}\left\{{ }^{1} \mathrm{H}\right\}$ NMR ( $376 \mathrm{MHz} \mathrm{CDCl}_{3}$ ): $\delta=-120.5 \mathrm{ppm}$. The spectral data match those previously reported. ${ }^{26}$

Synthesis and characterization of isoindoline (4): 1,2Bis(bromomethyl)benzene (1.32 g, $5 \mathrm{mmol}, 1$ equiv.), DIPEA (2.18 mL, $1.62 \mathrm{~g}, 12.5 \mathrm{mmol}, 2.5 \mathrm{eq}$ ), and aniline (o.68 mL, $0.698 \mathrm{~g}, 7.5 \mathrm{mmol}, 1.5$ equiv.) were dissolved in toluene $(25 \mathrm{~mL})$ and added to a sealed tube before vigorously stirring at $110{ }^{\circ} \mathrm{C}$ in an oil bath under a $\mathrm{N}_{2}$ atmosphere. The resulting mixture was cooled to down to room temperature and extracted with ethyl acetate $(3 \times 10 \mathrm{~mL})$. The combined organic phase was washed with brine, dried over anhydrous $\mathrm{Na}_{2} \mathrm{SO}_{4}$ and concentrated in vacuo. The crude product was purified by column chromatography (petroleum ether) to obtain the desired product $4(89 \%$ 
isolated yield, $0.87 \mathrm{~g}$ ) as a light yellow solid. ${ }^{1} \mathrm{H}$ NMR (400 $\left.\mathrm{MHz}, \mathrm{CDCl}_{3}\right): \delta=7.38-7.31(\mathrm{~m}, 6 \mathrm{H}), 6.78(\mathrm{dd}, J=7.6,7.6$ $\mathrm{Hz}, 1 \mathrm{H}), 6.71(\mathrm{~d}, J=7.6 \mathrm{~Hz}, 2 \mathrm{H}), 4.68(\mathrm{~s}, 4 \mathrm{H}) \mathrm{ppm}$. The spectral data match those previously reported. ${ }^{27}$

Synthesis and characterization of N-phenylphthalimide (5): In a Schlenk tube, Phthalic anhydride ( $0.74 \mathrm{~g}, 5 \mathrm{mmol}$, 1 equiv.), aniline (0.47 g, $5 \mathrm{mmol}$, 1 equiv.) and acetic acid ( $30 \mathrm{~mL}$ ) were refluxed in an oil bath for 2-5 h. Once at room temperature, water was added and the solid recovered by filtration. After drying under vacuum the desired phthalimide $\mathbf{5}$ (80\% isolated yield, o.89 $\mathrm{g}$ ) was obtained. ${ }^{1} \mathrm{H}$ NMR ( $400 \mathrm{MHz}, \mathrm{CDCl}_{3}$ ): $\delta=7.96$ (dd, $J=$ $5.6,3.2 \mathrm{~Hz}, 2 \mathrm{H}), 7.8 \mathrm{o}(\mathrm{dd}, J=5.2,3.2 \mathrm{~Hz}, 2 \mathrm{H}), 7.52(\mathrm{dd}, J=$ 7.6, $7.6 \mathrm{~Hz}, 2 \mathrm{H}), 7 \cdot 34-7.27(\mathrm{~m}, 3 \mathrm{H}) \mathrm{ppm}$. The spectral data match those previously reported. ${ }^{28}$

Synthesis and characterization of 2-Phenylhexahydro-1 $H$-isoindole-1,3(2H)-dione (6): Hexahydrophthalic anhydride (1.54 g, $10 \mathrm{mmol}, 1$ equiv.) and aniline (0.91 mL, $0.93 \mathrm{~g}, 10 \mathrm{mmol}, 1$ equiv.) and THF (15 mL) were added to a $100 \mathrm{~mL}$ round bottom flask. The solution was stirred for $30 \mathrm{~min}$. at $40{ }^{\circ} \mathrm{C}$ in an oil bath. Removal of the solvent using a rotary evaporator gave the corresponding carboxylic acid-amide as a white solid. The white solid was then heated at $190{ }^{\circ} \mathrm{C}$ under $\mathrm{Ar}$ for $4 \mathrm{~h}$. The desired hexahydrophthalimide 6 ( $86 \%$ isolated yield, $1.97 \mathrm{~g}$ ) was purified by silica gel column chromatography (petroleum ether/EtOAc gradient 10:1 to 2:1). ${ }^{1} \mathrm{H}$ NMR (400 MHz, $\left.\mathrm{CDCl}_{3}\right): \delta=7.48-7.44(\mathrm{~m}, 2 \mathrm{H}), 7 \cdot 39-7.35\left(\mathrm{~m},{ }_{1} \mathrm{H}\right), 7 \cdot 30-7.27$ $(\mathrm{m}, 2 \mathrm{H})$, 3.06-3.00 (m, 2H), 1.95-1.85 (m, $4 \mathrm{H}), 1.53^{-1.50}(\mathrm{~m}$, $\left.{ }_{4} \mathrm{H}\right) \mathrm{ppm}$. The spectral data match those previously reported. ${ }^{29}$

General procedure for the arylation reactions, and characterization of products 2 : $\left[\mathrm{RuCl}_{2}(p \text {-cymene })\right]_{2}(9.2$ $\mathrm{mg}$, 0.015 mmol, 5 mol\%), $\mathrm{AgSbF}_{6}(20.6 \mathrm{mg}, 0.06 \mathrm{mmol}, 20$ mol\%), $\mathrm{Ag}_{2} \mathrm{O}$ (69.5 mg, $0.3 \mathrm{mmol}$, 1.o equiv.), $\mathrm{Cu}(\mathrm{OTf})_{2}$ (21.7 mg, o.06 mmol, $20 \mathrm{~mol} \%$ ), the corresponding $N$-arylisoindolinone derivative $\mathbf{1}$ ( $0.3 \mathrm{mmol}, 1.0$ equiv.) and the corresponding phenylboronic acid derivative ( $0.75 \mathrm{mmol}$, 2.5 equiv.) were taken in a $15 \mathrm{~mL}$ Schlenk tube, which was equipped with a magnetic stirrer bar. THF $(1.5 \mathrm{~mL})$ was added to the Schlenk tube via a syringe, and the reaction mixture was degassed with Argon three times. The reaction mixture was allowed to stir at 90 or $110^{\circ} \mathrm{C}$ for $20 \mathrm{~h}$ in an oil bath. After being cooled to ambient temperature, the reaction mixture was diluted with DCM and then filtered through Celite. After evaporation of the solvent in vacuo, the crude product was purified by column chromatography on silica gel ( $n$-heptane/EtOAc gradient 10:1 to 5:1) to give the desired product 2.

2-([1,1'-Biphenyl]-2-yl)isoindolin-1-one (2a): $61.6 \mathrm{mg}$ (72\% yield), white solid, Mp: < 50 ${ }^{\circ} \mathrm{C}$. ${ }^{1} \mathrm{H}$ NMR (40o MHz, $\left.\mathrm{CDCl}_{3}\right): \delta=7.93\left(\mathrm{~d}, J=7.2 \mathrm{~Hz},{ }_{1 \mathrm{H}}\right), 7.52-7.43(\mathrm{~m}, 6 \mathrm{H}), 7.4 \mathrm{O}^{-}$ $7.38(\mathrm{~m}, 2 \mathrm{H}), 7 \cdot 32-7.24(\mathrm{~m}, 4 \mathrm{H}), 4.17(\mathrm{~s}, 2 \mathrm{H}) \mathrm{ppm} .{ }^{13} \mathrm{C}\left\{{ }^{1} \mathrm{H}\right\}$ NMR (10o $\mathrm{MHz}, \mathrm{CDCl}_{3}$ ): $\delta=169.0,141.7,139.9,139.2$, 135.9, 132.2, 131.7, 131.1, 129.1, 128.7, 128.6, 128.4, 128.3, 128.1, 127.6, 124.3, 122.7, $52.3 \mathrm{ppm}$. HRMS (ESI) calcd. for $[\mathrm{M}+\mathrm{Na}]^{+}$ $\mathrm{C}_{20} \mathrm{H}_{15} \mathrm{NONa} 308.1046$, found 308.1050 (1 ppm).
2-(5-Methyl-[1,1'-biphenyl]-2-yl)isoindolin-1-one (2b): $54.3 \mathrm{mg}$ (6o\% yield), white solid, Mp: $167-169{ }^{\circ} \mathrm{C} .{ }^{1} \mathrm{H}$ NMR $\left(400 \mathrm{MHz}, \mathrm{CDCl}_{3}\right): \delta=7.93(\mathrm{~d}, J=7.2 \mathrm{~Hz}, 1 \mathrm{H}), 7.51-7.44(\mathrm{~m}$, 2H), 7.40-7.35 (m, 3H), 7.31-7.22 (m, 6H), $4.16(\mathrm{~s}, 2 \mathrm{H}), 2.44$ $\left(\mathrm{s},{ }_{3} \mathrm{H}\right)$ ppm. ${ }^{13} \mathrm{C}\left\{{ }^{1} \mathrm{H}\right\}$ NMR (100 $\left.\mathrm{MHz}, \mathrm{CDCl}_{3}\right): \delta=169.1,141.7$, 139.7, 139.2, 138.2, 133.3, 132.3, 131.7, 131.6, 129.4, 128.9, 128.6, 128.4, 128.1, 127.5, 124.3, 122.7, 52.4, 21.3 ppm. HRMS (ESI) calcd. for $[\mathrm{M}+\mathrm{Na}]+\mathrm{C}_{21} \mathrm{H}_{17} \mathrm{NONa}$ 322.1202, found $322.12 \mathrm{O}$ (o ppm).

\section{2-(5-Methoxy-[1,1'-biphenyl]-2-yl)isoindolin-1-one} (2c): $79.1 \mathrm{mg}$ (84\% yield), white solid, Mp: $162-164{ }^{\circ} \mathrm{C} .{ }^{1} \mathrm{H}$ NMR (400 $\left.\mathrm{MHz}, \mathrm{CDCl}_{3}\right): \delta=7.92(\mathrm{~d}, J=7.2 \mathrm{~Hz}, 1 \mathrm{H}), 7.5^{-}$ $7.43(\mathrm{~m}, 2 \mathrm{H}), 7.41-7.36(\mathrm{~m}, 3 \mathrm{H}), 7.31-7.22(\mathrm{~m}, 4 \mathrm{H}), 7.01-6.98$ $(\mathrm{m}, 2 \mathrm{H}), 4.14(\mathrm{~s}, 2 \mathrm{H}), 3.86(\mathrm{~s}, 3 \mathrm{H}) \mathrm{ppm} .{ }^{13} \mathrm{C}\left\{{ }^{1} \mathrm{H}\right\}$ NMR (100 $\left.\mathrm{MHz}, \mathrm{CDCl}_{3}\right): \delta=169.2,159.2,141.6,141.2,139.0,132.2,131.5$, 130.2, 128.6, 128.3, 128.0, 127.7, 124.2, 122.6, 116.1, 114.1, 55.7, $52.6 \mathrm{ppm}$. HRMS (ESI) calcd. for $[\mathrm{M}+\mathrm{Na}]^{+} \mathrm{C}_{21} \mathrm{H}_{17} \mathrm{NO}_{2} \mathrm{Na}$ 338.1152, found 338.1153 (o ppm). Single crystals suitable for $\mathrm{X}$-ray diffraction studies were obtained after evaporation of a solution of $\mathbf{2 c}$ in acetone.

2-(5-Chloro-[1,1'-biphenyl]-2-yl)isoindolin-1-one (2d): $82.8 \mathrm{mg}$ (86\% yield), white solid, Mp: $121-123{ }^{\circ} \mathrm{C}$. ${ }^{1} \mathrm{H}$ NMR $\left(400 \mathrm{MHz}, \mathrm{CDCl}_{3}\right): \delta=7.91(\mathrm{~d}, J=7.2 \mathrm{~Hz}, 1 \mathrm{H}), 7.53-7.42(\mathrm{~m}$, $\left.{ }_{5} \mathrm{H}\right), 7.37-7.34(\mathrm{~m}, 2 \mathrm{H}), 7.33-7.26(\mathrm{~m}, 4 \mathrm{H}), 4.14(\mathrm{~s}, 2 \mathrm{H}) \mathrm{ppm}$. ${ }^{13} \mathrm{C}\left\{{ }^{1} \mathrm{H}\right\}$ NMR (10o $\mathrm{MHz}, \mathrm{CDCl}_{3}$ ): $\delta=169.1,141.6,141.4,137.9$, $134.6,133.8,131.92,131.90,131.0,130.4,128.9,128.7,128.3$, $128.24,128.16,124.4,122.8,52.1 \mathrm{ppm}$. HRMS (ESI) calcd. for $[\mathrm{M}+\mathrm{Na}]^{+} \mathrm{C}_{20} \mathrm{H}_{14} \mathrm{NO}^{35} \mathrm{ClNa} 342.0656$, found 342.0658 (1 ppm). Single crystals suitable for X-ray diffraction studies were obtained after evaporation of a solution of $\mathbf{2} \mathbf{d}$ in acetone.

Ethyl 6-(1-oxoisoindolin-2-yl)-[1,1'-biphenyl]-3-carboxylate (2e): $59.2 \mathrm{mg}$ ( $55 \%$ yield), white solid, Mp: < 50 ${ }^{\circ} \mathrm{C} .{ }^{1} \mathrm{H}$ NMR $\left(400 \mathrm{MHz} \mathrm{CDCl}_{3}\right): \delta=8.15(\mathrm{~d}, J=2.0 \mathrm{~Hz}, 1 \mathrm{H})$, $8.12(\mathrm{dd}, J=8.4,2.0 \mathrm{~Hz}, 1 \mathrm{H}), 7.92(\mathrm{~d}, J=7.2 \mathrm{~Hz}, 1 \mathrm{H}), 7.61(\mathrm{~d}$, $J=8.0 \mathrm{~Hz}, 1 \mathrm{H}), 7.54-7.45(\mathrm{~m}, 2 \mathrm{H}), 7.40(\mathrm{dd}, J=8.0,1.6 \mathrm{~Hz}$, $2 \mathrm{H}), 7 \cdot 35-7.27(\mathrm{~m}, 4 \mathrm{H}), 4.41(\mathrm{q}, J=7.2 \mathrm{~Hz}, 2 \mathrm{H}), 4.17(\mathrm{~s}, 2 \mathrm{H})$, $1.40(\mathrm{t}, J=7.2 \mathrm{~Hz}, 3 \mathrm{H})$ ppm. ${ }^{13} \mathrm{C}\left\{{ }^{1} \mathrm{H}\right\}$ NMR $\left(100 \mathrm{MHz}, \mathrm{CDCl}_{3}\right)$ : $\delta=168.9,166.0,141.6,140.2,139.4,138.5,132.6$, 132.0, 131.9, 130.0, 129.7, 129.0, 128.4, 128.3, 128.0, 124.4, 122.8, 61.3, 51.9, $14.5 \mathrm{ppm}$. HRMS (ESI) calcd. for $[\mathrm{M}+\mathrm{Na}]^{+} \mathrm{C}_{23} \mathrm{H}_{19} \mathrm{NO}_{3} \mathrm{Na}$ 380.1257, found 380.1259 (o ppm).

\section{2-(4-Phenylbenzo[d][1,3]dioxol-5-yl)isoindolin-1-one} (2g): $39.8 \mathrm{mg}$ (40\% yield), white solid, Mp: $212-214^{\circ} \mathrm{C} .{ }^{1} \mathrm{H}$ NMR (40o MHz, $\left.\mathrm{CDCl}_{3}\right): \delta=7.90\left(\mathrm{~d}, J=7.2 \mathrm{~Hz},{ }_{1} \mathrm{H}\right), 7.51^{-}$ $7.41\left(\mathrm{~m},{ }_{4} \mathrm{H}\right), 7.32-7.23\left(\mathrm{~m},{ }_{4} \mathrm{H}\right), 6.95\left(\mathrm{~d}, J=8.0 \mathrm{~Hz},{ }_{1} \mathrm{H}\right), 6.89$ $(\mathrm{d}, J=8.0 \mathrm{~Hz}, 1 \mathrm{H}), 6.02(\mathrm{~s}, 2 \mathrm{H}), 4.17(\mathrm{~s}, 2 \mathrm{H}) \mathrm{ppm} .{ }^{13} \mathrm{C}\left\{{ }^{1} \mathrm{H}\right\}$ NMR (10o $\mathrm{MHz}_{\mathrm{CDCl}}$ ): $\delta=169.4,147.3,146.2,141.6,132.7$, 132.2 , 131.7, 130.0, 129.1, 128.7, 128.2, 128.1, 124.4, 122.69, 122.65, 122.55, 108.0, 101.9, 52.9 ppm. HRMS (ESI) calcd. for $[\mathrm{M}+\mathrm{Na}]+\mathrm{C}_{21} \mathrm{H}_{15} \mathrm{NO}_{3} \mathrm{Na} 352.0944$, found 352.0947 (1 ppm). Single crystals suitable for X-ray diffraction studies were obtained after evaporation of a solution of $\mathbf{2} \mathbf{g}$ in acetone.

2-(4-Methyl-[1,1'-biphenyl]-2-yl)isoindolin-1-one (2h): $49.8 \mathrm{mg}$ (55\% yield), white solid, Mp: $<50{ }^{\circ} \mathrm{C} .{ }^{1} \mathrm{H}$ NMR (40o $\left.\mathrm{MHz}, \mathrm{CDCl}_{3}\right): \delta=7.93\left(\mathrm{~d}, J=6.8 \mathrm{~Hz},{ }_{1} \mathrm{H}\right), 7.52-7.44(\mathrm{~m}, 2 \mathrm{H})$, 7.38-7.35 (m, 3H), 7.30-7.23 (m, 6H), $4.16(\mathrm{~s}, 2 \mathrm{H}), 2.43(\mathrm{~s}$ 
$\left.{ }_{3} \mathrm{H}\right)$ ppm. ${ }^{13} \mathrm{C}\left\{{ }^{1} \mathrm{H}\right\}$ NMR (10o $\left.\mathrm{MHz}, \mathrm{CDCl}_{3}\right): \delta=169.2,141.7$, 139.2, 138.8, 137.0, 135.7, 132.3, 131.7, 131.0, 129.6, 129.3, 128.7, 128.5, 128.1, 127.4, 124.3, 122.7, 52.4, 21.2 ppm. HRMS (ESI) calcd. for $[\mathrm{M}+\mathrm{Na}]^{+} \mathrm{C}_{21} \mathrm{H}_{17} \mathrm{NONa}$ 322.1202, found 322.1205 (1 ppm).

\section{2-(4-Methoxy-[1,1'-biphenyl]-2-yl)isoindolin-1-one} (2i): $55.6 \mathrm{mg}$ (59\% yield), white solid, Mp: $142-144{ }^{\circ} \mathrm{C} .{ }^{1} \mathrm{H}$ NMR (40o $\mathrm{MHz}, \mathrm{CDCl}_{3}$ ): $\delta=7.93(\mathrm{~d}, J=7.2 \mathrm{~Hz}, 1 \mathrm{H}), 7.52-$ $7.44(\mathrm{~m}, 2 \mathrm{H}), 7.38-7.34(\mathrm{~m}, 3 \mathrm{H}), 7.29-7.20(\mathrm{~m}, 4 \mathrm{H}), 7.03^{-}$ $6.99(\mathrm{~m}, 2 \mathrm{H}), 4.17(\mathrm{~s}, 2 \mathrm{H}), 3.85(\mathrm{~s}, 3 \mathrm{H}) \mathrm{ppm} .{ }^{13} \mathrm{C}\left\{{ }^{1} \mathrm{H}\right\}$ NMR $\left(100 \mathrm{MHz}, \mathrm{CDCl}_{3}\right.$ ): $\delta=169.0,159.7,141.7,139.0,136.7,132.22$, 132.18, 131.9, 131.7, 128.7, 128.5, 128.1, 127.2, 124.3, 122.7, 114.7, 113.8, 55.6, 52.2 ppm. HRMS (ESI) calcd. for $[\mathrm{M}+\mathrm{Na}]^{+}$ $\mathrm{C}_{21} \mathrm{H}_{17} \mathrm{NO}_{2} \mathrm{Na} 338.1152$, found 338.1155 (1 ppm).

2-(2'-Fluoro-[1,1'-biphenyl]-2-yl)isoindolin-1-one (2l): $49.7 \mathrm{mg}$ ( $55 \%$ yield), white solid, Mp: $153-155{ }^{\circ} \mathrm{C}$. ${ }^{1} \mathrm{H}$ NMR $\left(400 \mathrm{MHz}, \mathrm{CDCl}_{3}\right): \delta=7.85(\mathrm{~d}, J=7.6 \mathrm{~Hz}, 1 \mathrm{H}), 7.53-7.42(\mathrm{~m}$, $6 \mathrm{H}), 7 \cdot 39-7.32(\mathrm{~m}, 2 \mathrm{H}), 7.27-7.21(\mathrm{~m}, 1 \mathrm{H}), 7.10-7.01(\mathrm{~m}, 2 \mathrm{H})$, 4.39 (s, 2H) ppm. ${ }^{13} \mathrm{C}\left\{{ }^{1} \mathrm{H}\right\}$ NMR (10o $\left.\mathrm{MHz}, \mathrm{CDCl}_{3}\right): \delta=168.2$, $159.4\left(\mathrm{~d}, J_{\mathrm{C}-\mathrm{F}}=245.0 \mathrm{~Hz}\right), 141.6,136.9,133.9,132.1,131.8\left(\mathrm{~d}, J_{\mathrm{C}-}\right.$ $\mathrm{F}=1.4 \mathrm{~Hz}), 131.7,131.5\left(\mathrm{~d}, J_{\mathrm{C}-\mathrm{F}}=3.1 \mathrm{~Hz}\right), 129.6\left(\mathrm{~d}, J_{\mathrm{C}-\mathrm{F}}=8.0\right.$ $\mathrm{Hz}), 129.3,128.4,128.1,127.9,126.7$ (d, $\left.J_{\mathrm{C}-\mathrm{F}}=15.4 \mathrm{~Hz}\right), 124.4$ $\left(\mathrm{d}, J_{\mathrm{C}-\mathrm{F}}=3.6 \mathrm{~Hz}\right), 124.3,122.7,115.7\left(\mathrm{~d}, J_{\mathrm{C}-\mathrm{F}}=22.1 \mathrm{~Hz}\right), 52.3(\mathrm{~d}$, $\left.J_{\mathrm{C}-\mathrm{F}}=1.4 \mathrm{~Hz}\right)$ ppm. ${ }^{19} \mathrm{~F}\left\{{ }^{1} \mathrm{H}\right\}$ NMR $\left(376 \mathrm{MHz}, \mathrm{CDCl}_{3}\right): \delta=-$ $116.4 \mathrm{ppm}$. HRMS (ESI) calcd. for $[\mathrm{M}+\mathrm{Na}]^{+} \mathrm{C}_{20} \mathrm{H}_{14} \mathrm{NOFNa}$ 326.0952, found 326.0952 (o ppm).

2-(2'-Methoxy-[1,1'-biphenyl]-2-yl)isoindolin-1-one (2m): $41.3 \mathrm{mg}$ (44\% yield), white solid, Mp: $120-122{ }^{\circ} \mathrm{C} .{ }^{1} \mathrm{H}$ NMR (40o MHz, $\left.\mathrm{CDCl}_{3}\right): \delta=7.88(\mathrm{~d}, J=7.6 \mathrm{~Hz}, 1 \mathrm{H}), 7.51^{-}$ $7.40(\mathrm{~m}, 6 \mathrm{H}), 7.30-7.22(\mathrm{~m}, 3 \mathrm{H}), 6.91(\mathrm{dd}, J=7.6,7.2 \mathrm{~Hz}$, $1 \mathrm{H}), 6.84(\mathrm{~d}, J=8.0 \mathrm{~Hz}, 1 \mathrm{H}), 4.24(\mathrm{~s}, 2 \mathrm{H}), 3.66(\mathrm{~s}, 3 \mathrm{H}) \mathrm{ppm}$. ${ }^{13} \mathrm{C}\left\{{ }^{1} \mathrm{H}\right\}$ NMR (10o $\left.\mathrm{MHz}, \mathrm{CDCl}_{3}\right): \delta=168.2,156.4,141.7,137.0$, $136.3,132.5,132.1,131.5,131.1,129.3,128.5,128.4,128.1,128.0$, $127.5,124.2,122.6,120.9,110.8,55.6,52.0$ ppm. HRMS (ESI) calcd. for $[\mathrm{M}+\mathrm{Na}]^{+} \mathrm{C}_{21} \mathrm{H}_{17} \mathrm{NO}_{2} \mathrm{Na} 338.1152$, found 338.1150 (o ppm). Single crystals suitable for X-ray diffraction studies were obtained after evaporation of a solution of $\mathbf{2} \mathbf{m}$ in acetone.

2-(3'-Chloro-[1,1'-biphenyl]-2-yl)isoindolin-1-one (2n): $14.8 \mathrm{mg}$ (15\% yield), yellow solid, Mp: $128-130{ }^{\circ} \mathrm{C}$. ${ }^{1} \mathrm{H}$ NMR $\left(400 \mathrm{MHz}, \mathrm{CDCl}_{3}\right): \delta=7.93(\mathrm{~d}, J=7.2 \mathrm{~Hz}, 1 \mathrm{H}), 7 \cdot 55-7.44(\mathrm{~m}$, $6 \mathrm{H}), 7.40(\mathrm{~s}, 1 \mathrm{H}), 7.32(\mathrm{~d}, J=7.2 \mathrm{~Hz}, 1 \mathrm{H}), 7.28-7.23(\mathrm{~m}, 2 \mathrm{H})$, $7.18(\mathrm{dd}, J=7.6,7.6 \mathrm{~Hz}, 1 \mathrm{H}), 4.23(\mathrm{~s}, 2 \mathrm{H}) \mathrm{ppm} .{ }^{13} \mathrm{C}\left\{{ }^{1} \mathrm{H}\right\} \mathrm{NMR}$ $\left(100 \mathrm{MHz}, \mathrm{CDCl}_{3}\right): \delta=169.1,141.6,141.0,138.7,136.1,134.6$, 132.1, 131.9, 131.0, 130.0, 129.3, 129.2, 128.6, 128.5, 128.3, 127.8, $126.8,124.4,122.8,52.5 \mathrm{ppm}$. HRMS (ESI) calcd. for [M + $\mathrm{Na}]^{+} \mathrm{C}_{20} \mathrm{H}_{14} \mathrm{NO}^{35} \mathrm{ClNa} 342.0656$, found 342.0654 (1 ppm). Single crystals suitable for X-ray diffraction studies were obtained after evaporation of a solution of $\mathbf{2 n}$ in acetone.

2-(3'-Methyl-[1,1'-biphenyl]-2-yl)isoindolin-1-one (20): $66.7 \mathrm{mg}$ (74\% yield), white solid, Mp: 146-148 ${ }^{\circ} \mathrm{C}$. ${ }^{1} \mathrm{H}$ NMR $\left(400 \mathrm{MHz}, \mathrm{CDCl}_{3}\right): \delta=7.94\left(\mathrm{~d}, J=6.4 \mathrm{~Hz},{ }_{1} \mathrm{H}\right), 7.52-7.40$ $(\mathrm{m}, 6 \mathrm{H}), 7.27(\mathrm{~d}, J=7.6 \mathrm{~Hz}, 1 \mathrm{H}), 7.22(\mathrm{~s}, 1 \mathrm{H}), 7.20-7.14(\mathrm{~m}$, $2 \mathrm{H}), 7.06(\mathrm{~d}, J=7.2 \mathrm{~Hz}, 1 \mathrm{H}), 4.18(\mathrm{~s}, 2 \mathrm{H}), 2.26(\mathrm{~s}, 3 \mathrm{H}) \mathrm{ppm}$. ${ }^{13} \mathrm{C}\left\{{ }^{1} \mathrm{H}\right\} \mathrm{NMR}\left(100 \mathrm{MHz}, \mathrm{CDCl}_{3}\right): \delta=169.0,141.7,139.9$, 139.0, $138.3,135.9,132.2,131.6,131.0,129.1,129.0,128.52,128.48$, 128.3, 128.2, 128.0, 125.4, 124.2, 122.7, 52.2, 21.4 ppm. HRMS
(ESI) calcd. for $[\mathrm{M}+\mathrm{Na}]^{+} \mathrm{C}_{21} \mathrm{H}_{17} \mathrm{NONa}$ 322.1202, found 322.1203 (o ppm). Single crystals suitable for X-ray diffraction studies were obtained after evaporation of a solution of $\mathbf{2 0}$ in acetone.

2-(3'-Methoxy-[1,1'-biphenyl]-2-yl)isoindolin-1-one (2p): $30.7 \mathrm{mg}$ (32\% yield), white solid, Mp: <50 ${ }^{\circ} \mathrm{C}$. ${ }^{1} \mathrm{H}$ NMR $\left(400 \mathrm{MHz}, \mathrm{CDCl}_{3}\right): \delta=7.93(\mathrm{~d}, J=7.2 \mathrm{~Hz}, 1 \mathrm{H}), 7.53-7.42(\mathrm{~m}$, $6 \mathrm{H}), 7.29(\mathrm{~d}, J=7.2 \mathrm{~Hz}, 1 \mathrm{H}), 7.20(\mathrm{dd}, J=8.0,8.0 \mathrm{~Hz}, 1 \mathrm{H})$, 7.00-6.94 (m, 2H), 6.82-6.79 (m, 1H), $4.19(\mathrm{~s}, 2 \mathrm{H}), 3.65(\mathrm{~s}$, $3 \mathrm{H})$ ppm. ${ }^{13} \mathrm{C}\left\{{ }^{1} \mathrm{H}\right\}$ NMR (10o $\left.\mathrm{MHz}, \mathrm{CDCl}_{3}\right): \delta=169.1,159.7$, 141.8 , 140.5, 139.8, 135.9, 132.2, 131.7, 131.0, 129.8, 129.2, 128.8, $128.4,128.2,124.3,122.8,120.9,114.0,113.3,55.3,52.3 \mathrm{ppm}$. HRMS (ESI) calcd. for $[\mathrm{M}+\mathrm{Na}]^{+} \mathrm{C}_{21} \mathrm{H}_{17} \mathrm{NO}_{2} \mathrm{Na} 338.1152$, found 338.1149 (1 ppm).

2-(3'-Nitro-[1,1'-biphenyl]-2-yl)isoindolin-1-one (2q): $58.8 \mathrm{mg}$ (6o\% yield), yellow solid, Mp: $226-228^{\circ} \mathrm{C} .{ }^{1} \mathrm{H}$ NMR $\left(400 \mathrm{MHz} \mathrm{CDCl}_{3}\right): \delta=8.25(\mathrm{dd}, J=2.0,2.0 \mathrm{~Hz}, 1 \mathrm{H}), 8.10$ $(\mathrm{dd}, J=8.0,2.0 \mathrm{~Hz}, 1 \mathrm{H}), 7.85(\mathrm{~d}, J=7.6 \mathrm{~Hz}, 1 \mathrm{H}), 7.73(\mathrm{~d}, J=$ $7.6 \mathrm{~Hz}, 1 \mathrm{H}), 7.55-7.41(\mathrm{~m}, 7 \mathrm{H}), 7.35\left(\mathrm{~d}, J=7.6 \mathrm{~Hz},{ }_{1} \mathrm{H}\right), 4.36$ (s, 2H) ppm. ${ }^{13} \mathrm{C}\left\{{ }^{1} \mathrm{H}\right\}$ NMR (10o $\left.\mathrm{MHz}, \mathrm{CDCl}_{3}\right): \delta=168.7$, 148.4, 141.3, 141.0, 138.0, 136.1, 134.7, 132.0, 131.8, 130.9, 129.8, 129.6, 129.0, 128.7, 128.4, 124.3, 123.3, 122.8, 122.5, 52.8 ppm. HRMS (ESI) calcd. for $[\mathrm{M}+\mathrm{Na}]^{+} \mathrm{C}_{20} \mathrm{H}_{14} \mathrm{~N}_{2} \mathrm{O}_{3} \mathrm{Na} 353.0897$, found 353.0898 (o ppm).

2-(3',5'-Dimethyl-[1,1'-biphenyl]-2-yl)isoindolin-1-one (2r): $58.7 \mathrm{mg}\left(62 \%\right.$ yield), white solid, Mp: $169-171^{\circ} \mathrm{C} .{ }^{1} \mathrm{H}$ $\operatorname{NMR}\left(400 \mathrm{MHz}, \mathrm{CDCl}_{3}\right): \delta=7.94(\mathrm{~d}, J=7.2 \mathrm{~Hz}, 1 \mathrm{H}), 7.52-$ $7.41(\mathrm{~m}, 6 \mathrm{H}), 7.29(\mathrm{~d}, J=6.8 \mathrm{~Hz}, 1 \mathrm{H}), 6.99(\mathrm{~s}, 2 \mathrm{H}), 6.88(\mathrm{~s}$, $1 \mathrm{H}), 4.17$ (s, 2H), 2.19 (s, 6H) ppm. ${ }^{13} \mathrm{C}\left\{{ }^{1} \mathrm{H}\right\}$ NMR (10o MHz, $\left.\mathrm{CDCl}_{3}\right): \delta=169.1,141.8,139.9,139.1,138.2,135.9,132.3,131.6$, 131.1, 129.3, 129.1, 128.4, 128.2, 128.1, 126.2, 124.3, 122.7, 52.2, $21.3 \mathrm{ppm}$. HRMS (ESI) calcd. for $[\mathrm{M}+\mathrm{Na}]+\mathrm{C}_{22} \mathrm{H}_{19} \mathrm{NONa}$ 336.1359, found 336.1363 (1 ppm).

2-(4'-Methyl-[1,1'-biphenyl]-2-yl)isoindolin-1-one (2s): $68.8 \mathrm{mg}$ (77\% yield), white solid, Mp: $132-134{ }^{\circ} \mathrm{C}$. ${ }^{1} \mathrm{H}$ NMR $\left(400 \mathrm{MHz}, \mathrm{CDCl}_{3}\right): \delta=7.94(\mathrm{~d}, J=7.6 \mathrm{~Hz}, 1 \mathrm{H}), 7.53-7.42(\mathrm{~m}$, $6 \mathrm{H}), 7.29-7.26(\mathrm{~m}, 3 \mathrm{H}), 7.10(\mathrm{~d}, J=7.2 \mathrm{~Hz}, 2 \mathrm{H}), 4.20(\mathrm{~s}, 2 \mathrm{H})$, 2.30 (s, $3 \mathrm{H})$ ppm. ${ }^{13} \mathrm{C}\left\{{ }^{1} \mathrm{H}\right\}$ NMR (100 $\left.\mathrm{MHz}, \mathrm{CDCl}_{3}\right): \delta=169.0$, $141.7,139.8,137.3,136.2,135.9,132.3,131.6,131.2,129.5,129.1$, $128.4,128.29,128.28,128.1,124.3,122.8,52.2,21.2 \mathrm{ppm}$. HRMS (ESI) calcd. for $[\mathrm{M}+\mathrm{Na}]+\mathrm{C}_{21} \mathrm{H}_{17} \mathrm{NONa} 322.1202$, found 322.1201 (o ppm).

2-(4'-Methoxy-[1,1'-biphenyl]-2-yl)isoindolin-1-one (2t): $74.5 \mathrm{mg}$ (79\% yield), white solid, $\mathrm{Mp}:<50{ }^{\circ} \mathrm{C} .{ }^{1} \mathrm{H}$ NMR $\left(400 \mathrm{MHz}, \mathrm{CDCl}_{3}\right): \delta=7.93\left(\mathrm{~d}, J=6.8 \mathrm{~Hz},{ }_{1} \mathrm{H}\right), 7 \cdot 51^{-7.41}(\mathrm{~m}$, $6 \mathrm{H}), 7.33-7.28(\mathrm{~m}, 3 \mathrm{H}), 6.83(\mathrm{dd}, J=6.8,2.0 \mathrm{~Hz}, 2 \mathrm{H}), 4.2 \mathrm{O}$ (s, $2 \mathrm{H}), 3.75(\mathrm{~s}, 3 \mathrm{H})$ ppm. ${ }^{13} \mathrm{C}\left\{{ }^{1} \mathrm{H}\right\}$ NMR (100 MHz, $\left.\mathrm{CDCl}_{3}\right): \delta$ = 169.0, 159.1, 141.7, 139.5, 135.9, 132.3, 131.6, 131.4, 131.1, 129.6, 129.1, 128.3, 128.2, 128.1, 124.2, 122.8, 114.2, 55.2, $52.2 \mathrm{ppm}$. HRMS (ESI) calcd. for $[\mathrm{M}+\mathrm{Na}]+{ }^{+} \mathrm{C}_{21} \mathrm{H}_{17} \mathrm{NO}_{2} \mathrm{Na} 338.1152$, found 338.1147 (1 ppm).

2-(4'-Fluoro-[1,1'-biphenyl]-2-yl)isoindolin-1-one (2u): $16.9 \mathrm{mg}$ (19\% yield), yellow solid, Mp: $108-110{ }^{\circ} \mathrm{C} .{ }^{1} \mathrm{H}$ NMR $\left(400 \mathrm{MHz}, \mathrm{CDCl}_{3}\right): \delta=7.92(\mathrm{~d}, J=7.6 \mathrm{~Hz}, 1 \mathrm{H}), 7.54-7.43(\mathrm{~m}$, 6H), 7.38-7.30 (m, $3 \mathrm{H})$, 7.01-6.96 (m, 2H), $4.21(\mathrm{~s}, 2 \mathrm{H}) \mathrm{ppm}$. ${ }^{13} \mathrm{C}\left\{{ }^{1} \mathrm{H}\right\}$ NMR (100 MHz, $\left.\mathrm{CDCl}_{3}\right): \delta=169.1,162.4\left(\mathrm{~d}, J_{\mathrm{C}-\mathrm{F}}=\right.$ 
245.4 Hz), 141.6, 139.1, 136.0, 135.1 (d, J 131.8, 131.1, 130.1 (d, J $\left.J_{\text {C-F }}=8.0 \mathrm{~Hz}\right), 129.2,128.9,128.5,128.3$, 124.4, 122.8, $115.7\left(\mathrm{~d}, J_{\mathrm{C}-\mathrm{F}}=21.3 \mathrm{~Hz}\right), 52.4 \mathrm{ppm} .{ }^{19} \mathrm{~F}\left\{{ }^{1} \mathrm{H}\right\} \mathrm{NMR}$ $\left(376 \mathrm{MHz}, \mathrm{CDCl}_{3}\right): \delta=-114.6 \mathrm{ppm}$. HRMS (ESI) calcd. for $[\mathrm{M}+\mathrm{Na}]+{ }^{+} \mathrm{C}_{20} \mathrm{H}_{14} \mathrm{NOFNa} 326.0952$, found 326.0951 (o ppm).

2-(4'-Chloro-[1,1'-biphenyl]-2-yl)isoindolin-1-one (2v): $52.4 \mathrm{mg}$ (55\% yield), white solid, Mp: $141-143{ }^{\circ} \mathrm{C}$. ${ }^{1} \mathrm{H}$ NMR $\left(400 \mathrm{MHz}, \mathrm{CDCl}_{3}\right): \delta=7.92(\mathrm{~d}, J=7.6 \mathrm{~Hz}, 1 \mathrm{H}), 7.55-7.42(\mathrm{~m}$, $6 \mathrm{H}), 7.34-7.31(\mathrm{~m}, 3 \mathrm{H}), 7.26(\mathrm{~d}, J=8.4 \mathrm{~Hz}, 2 \mathrm{H}), 4.23(\mathrm{~s}, 2 \mathrm{H})$ ppm. ${ }^{13} \mathrm{C}\left\{{ }^{1} \mathrm{H}\right\}$ NMR (10o $\mathrm{MHz}, \mathrm{CDCl}_{3}$ ): $\delta=169.0,141.5$, 138.9, 137.6, 135.9, 133.7, 132.0, 131.9, 131.0, 129.8, 129.2, 129.1, 128.9, 128.5, 128.3, 124.3, 122.8, 52.4 ppm. HRMS (ESI) calcd. for $[\mathrm{M}+\mathrm{Na}]^{+} \mathrm{C}_{20} \mathrm{H}_{14} \mathrm{NO}^{35} \mathrm{ClNa} 342.0656$, found 342.0657 (o ppm).

2-(4'-Bromo-[1,1'-biphenyl]-2-yl)isoindolin-1-one (2w): $88.7 \mathrm{mg}$ (81\% yield), white solid, Mp: $138-140{ }^{\circ} \mathrm{C} .{ }^{1} \mathrm{H}$ NMR (400 $\left.\mathrm{MHz}, \mathrm{CDCl}_{3}\right): \delta=7.91(\mathrm{~d}, J=7.2 \mathrm{~Hz}, 1 \mathrm{H}), 7.55-7.40(\mathrm{~m}$, $8 \mathrm{H}), 7.32\left(\mathrm{~d}, J=7.2 \mathrm{~Hz},{ }_{1} \mathrm{H}\right), 7.27$ (ddd, $J=8.0,2.8,1.6 \mathrm{~Hz}$, 2H), $4.24(\mathrm{~s}, 2 \mathrm{H})$ ppm. ${ }^{13} \mathrm{C}\left\{{ }^{1} \mathrm{H}\right\}$ NMR (100 $\left.\mathrm{MHz}, \mathrm{CDCl}_{3}\right): \delta=$ 169.0, 141.5, 138.8, 138.1, 135.8, 132.0, 131.9, 131.8, 130.9, 130.1, 129.2, 129.1, 128.5, 128.2, 124.3, 122.8, 122.0, 52.4 ppm. HRMS (ESI) calcd. for $[\mathrm{M}+\mathrm{Na}]^{+} \mathrm{C}_{20} \mathrm{H}_{14} \mathrm{NO}^{79} \mathrm{BrNa} 386.0151$, found 386.0155 (1 ppm).

2-(2-(Naphthalen-2-yl)phenyl)isoindolin-1-one (2x): $83.1 \mathrm{mg}$ (83\% yield), white solid, Mp: $204-206{ }^{\circ} \mathrm{C}$. ${ }^{1} \mathrm{H}$ NMR $\left(400 \mathrm{MHz}, \mathrm{CDCl}_{3}\right): \delta=7.97-7.95(\mathrm{~m}, 1 \mathrm{H}), 7.92(\mathrm{~s}, 1 \mathrm{H}), 7.83^{-}$ $7.77(\mathrm{~m}, 2 \mathrm{H}), 7.73(\mathrm{~d}, J=8.4 \mathrm{~Hz}, 1 \mathrm{H}), 7.60-7.57(\mathrm{~m}, 1 \mathrm{H})$, 7.56-7.44 (m, 8H), 7.19-7.17 (m, 1H), 4.17 (s, 2H) ppm. ${ }^{13} \mathrm{C}\left\{{ }^{1} \mathrm{H}\right\}$ NMR (10o $\mathrm{MHz}, \mathrm{CDCl}_{3}$ ): $\delta=169.1,141.6,139.7,136.8$, 136.2, 133.5, 132.6, 132.1, 131.6, 131.4, 129.2, 128.8, 128.34, 128.31, 128.2, 128.1, 127.7, 127.4, 126.5, 126.3, 126.2, 124.2, 122.8, 52.3 ppm. HRMS (ESI) calcd. for $[\mathrm{M}+\mathrm{Na}]^{+} \mathrm{C}_{24} \mathrm{H}_{17} \mathrm{NONa}$ 358.1202, found 358.1206 (1 ppm).

2-(2-(6-Methoxynaphthalen-2-yl)phenyl)isoindolin-1one (2y): $76.7 \mathrm{mg}$ ( $70 \%$ yield), brown solid, Mp: $76-78^{\circ} \mathrm{C}$. ${ }^{1} \mathrm{H}$ NMR (40o $\mathrm{MHz} \mathrm{CDCl}_{3}$ ): $\delta=7.96-7.94\left(\mathrm{~m},{ }_{1} \mathrm{H}\right), 7.82$ (s, $\left.{ }_{1} \mathrm{H}\right), 7.69(\mathrm{~d}, J=9.2 \mathrm{~Hz}, 1 \mathrm{H}), 7.61\left(\mathrm{~d}, J=8.4 \mathrm{~Hz},{ }_{1} \mathrm{H}\right), 7.58-$ $7.55(\mathrm{~m}, 1 \mathrm{H}), 7.53-7.44(\mathrm{~m}, 6 \mathrm{H}), 7.20-7.18(\mathrm{~m}, 1 \mathrm{H}), 7.12(\mathrm{dd}$, $J=9.2,2.8 \mathrm{~Hz}, 1 \mathrm{H}), 7.07(\mathrm{~d}, J=2.8 \mathrm{~Hz}, 1 \mathrm{H}), 4.16(\mathrm{~s}, 2 \mathrm{H}), 3.89$ (s, $3 \mathrm{H})$ ppm. ${ }^{13} \mathrm{C}\left\{{ }^{1} \mathrm{H}\right\}$ NMR (100 $\mathrm{MHz}, \mathrm{CDCl}_{3}$ ): $\delta=169.2$, 158.1, 141.7, 139.8, 136.2, 134.6, 133.9, 132.2, 131.7, 131.4, 129.7, 129.2, 129.1, 128.6, 128.4, 128.1, 127.2, 127.1, 124.3, 122.8, 119.2, $105.7,55.4,52.3 \mathrm{ppm}$. HRMS (ESI) calcd. for $[\mathrm{M}+\mathrm{Na}]^{+}$ $\mathrm{C}_{25} \mathrm{H}_{19} \mathrm{NO}_{2} \mathrm{Na} 388.1308$, found 388.1310 (o ppm).

2-(2-(Naphthalen-1-yl)phenyl)isoindolin-1-one (2z): $9.8 \mathrm{mg}$ (10\% yield), brown solid, Mp: <50 ${ }^{\circ} \mathrm{C} .1 \mathrm{H} \mathrm{NMR}(400$ $\left.\mathrm{MHz}, \mathrm{CDCl}_{3}\right): \delta=7.83-7.75\left(\mathrm{~m},{ }_{4} \mathrm{H}\right), 7.62\left(\mathrm{~d}, J=8.0 \mathrm{~Hz},{ }_{1} \mathrm{H}\right)$, 7.58-7.35 (m, 9H), 7.09 (d, $J=8.0 \mathrm{~Hz}, 1 \mathrm{H}), 4.02(\mathrm{~d}, J=16.8$ $\mathrm{Hz}, 1 \mathrm{H}), 3.87(\mathrm{~d}, J=16.8 \mathrm{~Hz}, 1 \mathrm{H}) \mathrm{ppm} .{ }^{13} \mathrm{C}\left\{{ }^{1} \mathrm{H}\right\}$ NMR (100 $\left.\mathrm{MHz}_{\mathrm{CDCl}}\right): \delta=168.6,141.5,137.9,137.4,136.7,133.7,132.5$, $132.1,131.7,131.5,128.9,128.34,128.30,128.0,127.7,127.3$, 126.4, 126.1, 125.8, 125.6, 124.2, 122.6, 52.2 ppm. HRMS (ESI) calcd. for $[\mathrm{M}+\mathrm{Na}]+\mathrm{C}_{24} \mathrm{H}_{17} \mathrm{NONa}$ 358.1202, found 358.1202 (o ppm).

3,3'-Dichloro-1,1'-biphenyl (3): Colorless oil. ${ }^{1} \mathrm{H}$ NMR $\left(400 \mathrm{MHz}, \mathrm{CDCl}_{3}\right.$ ): $\delta=7.55$ (s, $\left.2 \mathrm{H}\right)$, 7.45-7.42 (m, 2H), 7.40-
$7 \cdot 33(\mathrm{~m}, 4 \mathrm{H})$ ppm. ${ }^{13} \mathrm{C}\left\{{ }^{1} \mathrm{H}\right\} \mathrm{NMR}\left(100 \mathrm{MHz}, \mathrm{CDCl}_{3}\right): \delta=141.7$, 135.0, 130.2, 128.0, 127.4, 125.4 ppm. MS (EI): $\mathrm{m} / \mathrm{z} 222\left(\mathrm{M}^{+}\right.$, 10o), 152 (77), 93 (20), 75 (22). The spectral data match those previously reported. $3^{0}$

Large scale synthesis of product $2 \mathrm{a}:\left[\mathrm{RuCl}_{2}(p \text {-cymene })\right]_{2}$ (30.6 mg, 0.05 mmol, 5 mol\%), AgSbF 6 (68.7 mg, 0.2 mmol, $20 \mathrm{~mol} \%), \mathrm{Ag}_{2} \mathrm{O}$ (231.7 mg, $1 \mathrm{mmol}$, 1.0 equiv.), $\mathrm{Cu}(\mathrm{OTf})_{2}$ (72.3 mg, $0.2 \mathrm{mmol}, 20 \mathrm{~mol} \%$ ), $N$-pheylisoindolinone ra (209.2 $\mathrm{mg}, 1 \mathrm{mmol}$, 1.0 equiv.) and phenylboronic acid (304.8 mg, 2.5 mmol, 2.5 equiv.) were taken in a $25 \mathrm{~mL}$ Schlenk tube, which was equipped with a magnetic stirrer bar. THF ( $5 \mathrm{~mL}$ ) was added to the Schlenk tube via a syringe, and the reaction mixture was degassed with Argon three times. The reaction mixture was allowed to stir at 110 ${ }^{\circ} \mathrm{C}$ for $20 \mathrm{~h}$ in an oil bath. After being cooled to ambient temperature, the reaction mixture was diluted with DCM and then filtered through Celite. After evaporation of the solvent in vacuo, the crude product was purified by column chromatography on silica gel ( $n$-heptane/EtOAc gradient 10:1 to 5:1) to give the desired product $2 \mathrm{a}(202.6 \mathrm{mg}$, $71 \%$ yield).

Late-stage ruthenium-catalyzed site-selective $\mathrm{C}-\mathrm{H}$ bond arylation of indoprofen (A): Indoprofen (A) was synthesized according to a literature procedure. ${ }^{31}$ Esterification step: Indoprofen (140.7 mg, $0.5 \mathrm{mmol}, 1$ equiv.) and concentrated $\mathrm{H}_{2} \mathrm{SO}_{4}(1$ drop) were stirred together in $\mathrm{EtOH}$ $(2 \mathrm{~mL})$ under reflux in an oil bath during 12 hours with a Dean-Stark condenser. Back at room temperature, solid sodium bicarbonate was added and the reaction mixture was filtered and concentrated under vacuum to afford the carboxylic acid ethyl ester indoprofen intermediate (7a) in quantitative yield and it was used without further purification for the next step. Ethyl 2-(4-(1-oxoisoindolin-2yl)phenyl)propanoate (7a): $153.0 \mathrm{mg}$ (99\% yield), yellow solid. ${ }^{1} \mathrm{H} \mathrm{NMR}\left(400 \mathrm{MHz}, \mathrm{CDCl}_{3}\right): \delta=7.84(\mathrm{~d}, J=7.6 \mathrm{~Hz}$, ${ }_{1 \mathrm{H}}$, 7.79-7.77 (m, $\left.2 \mathrm{H}\right), 7 \cdot 54-7.50(\mathrm{~m}, 1 \mathrm{H}), 7.45-7.41(\mathrm{~m}, 2 \mathrm{H})$, 7.33-7.30 (m, 2H), 4.74 (s, 2H), 4.15-4.05 (m, 2H), $3.68(\mathrm{q}, J$ $=7.2 \mathrm{~Hz}, 1 \mathrm{H}), 1.47(\mathrm{~d}, J=7.2 \mathrm{~Hz}, 3 \mathrm{H}), 1.19(\mathrm{t}, J=7.2 \mathrm{~Hz}, 3 \mathrm{H})$ ppm. ${ }^{13} \mathrm{C}\left\{{ }^{1} \mathrm{H}\right\}$ NMR (10o $\left.\mathrm{MHz}, \mathrm{CDCl}_{3}\right): \delta=174.4,167 \cdot 3,140.1$, 138.4, 136.6, 133.0, 132.0, 128.3, 128.1, 123.9, 122.6, 119.4, 60.7, 50.6, 44.9, 18.5, 14.1 ppm ppm. The spectral data match those previously reported. ${ }^{32} \mathrm{Ru}$-catalyzed $\mathrm{C}-\mathrm{H}$ bond arylation: $\left[\mathrm{RuCl}_{2} \text { (p-cymene) }\right]_{2}$ (15.3 $\mathrm{mg}$, $\left.0.025 \mathrm{mmol}, 5 \mathrm{~mol} \%\right)$, $\mathrm{AgSbF}_{6}$ (34.4 mg, o.1 mmol, 20 mol\%), $\mathrm{Ag}_{2} \mathrm{O}$ (115.9 mg, 0.5 mmol, 1.o equiv.), $\mathrm{Cu}(\mathrm{OTf})_{2}(36.2 \mathrm{mg}$, o.1 mmol, $20 \mathrm{~mol} \%)$, indoprofen derivative 7 a (153.0 $\mathrm{mg}, 0.5 \mathrm{mmol}, 1.0$ equiv.) and phenylboronic acid (152.4 $\mathrm{mg}, 1.25 \mathrm{mmol}, 2.5$ equiv.) were taken in a $15 \mathrm{~mL}$ Schlenk tube, which was equipped with a magnetic stirrer bar. THF $(2.5 \mathrm{~mL})$ was added to the Schlenk tube via a syringe, and the reaction mixture was degassed with Argon three times. The reaction mixture was allowed to stir at $110{ }^{\circ} \mathrm{C}$ for $20 \mathrm{~h}$ in an oil bath. After being cooled to ambient temperature, the reaction mixture was diluted with DCM and then filtered through Celite. After evaporation of the solvent in vacuo, the crude product was purified by column chromatography on silica gel ( $n$-heptane/EtOAc gradient 10:1 to 5:1) to give the arylated product $\mathbf{7 b}$. Ethyl 2-(6-(1-oxoisoindolin-2-yl)-[1,1'biphenyl]-3-yl)propanoate ( $7 \mathbf{b}): 160.1 \mathrm{mg}$ ( $85 \%$ yield), colourless oil. ${ }^{1} \mathrm{H}$ NMR (40o $\left.\mathrm{MHz} \mathrm{CDCl}_{3}\right): \delta=7.92(\mathrm{~d}, J=$ 
6.8 Hz, $1 \mathrm{H}), 7.52-7.39(\mathrm{~m}, 7 \mathrm{H}), 7 \cdot 32-7.23(\mathrm{~m}, 4 \mathrm{H}), 4.23-4.10$ $(\mathrm{m}, 4 \mathrm{H}), 3.81(\mathrm{q}, J=7.2 \mathrm{~Hz}, 1 \mathrm{H}), 1.56(\mathrm{~d}, J=7.2 \mathrm{~Hz}, 3 \mathrm{H}), 1.27$ $(\mathrm{t}, J=7.2 \mathrm{~Hz}, 3 \mathrm{H})$ ppm. ${ }^{13} \mathrm{C}\left\{{ }^{1} \mathrm{H}\right\}$ NMR (100 MHz, $\left.\mathrm{CDCl}_{3}\right): \delta=$ 174.2, 169.0, 141.6, 140.6, 139.8, 138.9, 134.7, 132.0, 131.6, 130.2, 129.1, 128.6, 128.3, 128.0, 127.7, 127.6, 124.2, 122.6, 60.9, 52.2, $45.3,18.7,14.2 \mathrm{ppm}$. HRMS (ESI) calcd. for $[\mathrm{M}+\mathrm{Na}]^{+}$ $\mathrm{C}_{25} \mathrm{H}_{23} \mathrm{NO}_{3} \mathrm{Na} 408.1570$, found 408.1573 (1 ppm). Ester hydrolysis: 7 b (106 mg, 0.27 mmol, 1 equiv.) and $2 \mathrm{M} \mathrm{NaOH}$ $(1 \mathrm{~mL})$ were stirred in a mixture of $\mathrm{MeOH}(1 \mathrm{~mL})$ and THF ( $1 \mathrm{~mL}$ ) at room temperature for 12 hours. Then, the reaction mixture was basified to $\mathrm{pH} 14$ and washed with ethyl acetate three times. The aqueous layer was acidified to $\mathrm{pH}$ 1 with concentrated $\mathrm{HCl}$ and the product 7 precipitated out. After washing with pentane and drying under vacuum, product 7 was isolated. 2-(6-(1-Oxoisoindolin-2yl)-[1,1'-biphenyl]-3-yl)propanoic acid (7): $86.8 \mathrm{mg}$ (90\% yield), white solid, Mp: $208-210{ }^{\circ} \mathrm{C} .{ }^{1} \mathrm{H}$ NMR (400 $\left.\mathrm{MHz}, \mathrm{CDCl}_{3}\right): \delta=7.92\left(\mathrm{~d}, J=7.6 \mathrm{~Hz},{ }_{1 \mathrm{H}}\right), 7 \cdot 52-7.41\left(\mathrm{~m},{ }_{5} \mathrm{H}\right)$, 7.39-7.35 (m, 2H), 7.31-7.24 (m, 4H), $4.16(\mathrm{~s}, 2 \mathrm{H}), 3.83(\mathrm{q}, J$ $=7.2 \mathrm{~Hz}, 1 \mathrm{H}), 1.57(\mathrm{~d}, J=7.2 \mathrm{~Hz}, 3 \mathrm{H}) \mathrm{ppm} .{ }^{13} \mathrm{C}\left\{{ }^{1} \mathrm{H}\right\}$ NMR $(100$ $\left.\mathrm{MHz}, \mathrm{CDCl}_{3}\right): \delta=179.2,169.4,141.7,140.2,140.0,138.9$, 134.9, 132.0, 131.8, 130.5, 129.3, 128.8, 128.5, 128.2, 128.0, 127.7, $124.4,122.7,52.4,45.2,18.4$ ppm. HRMS (ESI) calcd. for [M $+\mathrm{Na}]^{+} \mathrm{C}_{23} \mathrm{H}_{19} \mathrm{NO}_{3} \mathrm{Na} 380.1257$, found 380.1263 (2 ppm).

\section{ASSOCIATED CONTENT}

Supporting Information.

The Supporting Information is available free of charge on the ACS Publications website at DOI: xxx.

${ }^{1} \mathrm{H}$ NMR spectra for known compounds, and ${ }^{1} \mathrm{H}$ and ${ }^{13} \mathrm{C}\left\{{ }^{1} \mathrm{H}\right\}$ NMR spectra for all new compounds, and X-ray crystallography data $(\mathrm{PDF})$

$\mathrm{X}$-ray crystallography of $\mathbf{2 c}(\mathrm{CIF})$

X-ray crystallography of $\mathbf{2 d}$ (CIF)

X-ray crystallography of $\mathbf{2 g}$ (CIF)

$\mathrm{X}$-ray crystallography of $\mathbf{2 m}$ (CIF)

$\mathrm{X}$-ray crystallography of $\mathbf{2 n}$ (CIF)

$\mathrm{X}$-ray crystallography of $\mathbf{2 0}$ (CIF)

\section{AUTHOR INFORMATION}

\section{Corresponding Author}

*E-mail: rafael.gramage-doria@univ-rennesı.fr ORCID

Christian Bruneau: oooo-00o2-2220-1458

Thierry Roisnel: oooo-0oo2-6o88-4472

Rafael Gramage-Doria: oooo-0oo2-0961-4530

Notes

The authors declare no competing financial interest.

\section{ACKNOWLEDGMENT}

CNRS, Université de Rennes 1, Rennes Metropole, China Scholarship Council (PhD grant to Y.-C.Y.), Agence Nationale de la Recherche (ANR-JCJC) and COST Action CA15106 (CHAOS) are acknowledged.

\section{REFERENCES}

(1) Donohoe, T. J. Product class 14: $1 \mathrm{H}$ - and $2 \mathrm{H}$-isoindoles. Sci. Synth. 2001, 10, 653-692.

(2) (a) Speck, K.; Magauer, T. The chemistry of isoindole natural products. Beilstein J. Org. Chem. 2013, 9, 2048-2078. (b)
Bhatia, R. K. Isoindole Derivatives: Propitious Anticancer Structural Motifs. Curr. Top. Med. Chem. 2017, 17, 189-207.

(3) Iqbal, A.; Herren, F.; Wallquist, O. in High Performance Pigments, 2nd ed., (Eds.: E. B. Faulkner, R. J. Schwartz), Wiley$\mathrm{VCH}$, Weinheim, 2009, pp. 243-259).

(4) Lunn, M. R.; Root, D. E.; Martino, A. M.; Flaherty, S. P.; Kelley, B. P.; Coovert, D. D.; Burghes, A. H.; Man, Nguyen, T. M.; Morris, G. E.; Zhou, J.; Androphy, E. J.; Sumner, C. J.; Stockwell, B. R. Indoprofen Upregulates the Survival Motor Neuron Protein through a Cyclooxygenase-Independent Mechanism. Chem. Biol. 2004, 11, 1489-1493.

(5) (a) Miyachi, H.; Azuma, A.; Hioki, E.; Kobayashi, Y.; Iwasaki, S.; Hashimoto, Y. Inducer-specific regulators of tumor necrosis factor alpha production. Chem. Pharm. Bull. 1996, 44, 1980-1982. (b) Park, J. S.; Moon, S. C.; Baik, K. U.; Cho, J. Y.; Yoo, E. S.; Byun, Y. S.; Park, M. H. Synthesis and SAR studies for the inhibition of TNF- $\alpha$ production. Part 2. 2-[3-(Cyclopentyloxy)-4-methoxyphenyl]-substituted-1-isoindolinone derivatives. Arch. Pharm. Res. 2002, 25, 137-142.

(6) Hamprecht, D.; Micheli, F.; Tedesco, G.; Checchia, A.; Donati, D.; Petrone, M.; Terreni, S.; Wood, M. Isoindolone derivatives, a new class of $5-\mathrm{HT}_{2} \mathrm{C}$ antagonists: Synthesis and biological evaluation. Bioorg. Med. Chem. Lett. 2007, 17, 428-433.

(7) (a) Allin, S. M.; Northfield, C. J.; Page, M. I.; Slawin, A. M. $\mathrm{Z}$. Approaches to the synthesis of non-racemic 3-substituted isoindolinone derivatives. J. Chem. Soc., Perkin Trans. 1 2ooo, 200o, 1715-1721. (b) Enders, D.; Braig, V.; Raabe, G. Asymmetric synthesis of 3-aryl-substituted 2,3-dihydro-1H-isoindol-1-ones. Can. J. Chem. 2001, 79, 1528-1535. (c) Hunter, R.; Richards, P. Stereoselective tetrapyrido[2,1-a]isoindolone synthesis via carbanionic and radical intermediates: a model study for the Tacaman alkaloid D/E ring fusion. Org. Biomol. Chem. 2003, 1, 2348-2356. (d) Csende, F.; Stajer, G. Approaches to the formation of condensed isoindolones. Curr. Org. Chem. 2005, 9, 1261-1276. (e) Stajer, G.; Csende, F. Advanced methods for the synthesis of 3 -substituted $1 \mathrm{H}$-isoindol-1-ones. Curr. Org. Chem. 2005, 9, 1277-1286. (f) Yuan, Y.-C.; Bruneau, C.; Gramage-Doria, R. Merging Transition-Metal Catalysis with Phthalimides: A New Entry to Useful Building Blocks. Synthesis 2018, 50, 4216-4228. (g) Thapa, P.; Corral, E.; Sardar, S.; Pierce, B. S.; Foss Jr., F. W. Isoindolinone Synthesis: Selective Dioxane-Mediated Aerobic Oxidation of Isoindolines. J. Org. Chem. 2019, 84, 1025-1034.

(8) (a) Engle, K. M.; Mei, T.-S.; Wasa, M.; Yu, J.-Q. Weak Coordination as a Powerful Means for Developing Broadly Useful C-H Functionalization Reactions. Acc. Chem. Res. 2012, 45, 788-802. (b) De Sarkar, S.; Liu, W.; Kozhushkov, S. I.; Ackermann, L. Weakly Coordinating Directing Groups for Ruthenium(II)-Catalyzed C-H Activation. Adv. Synth. Catal. 2014, 356, 1461-1479. (c) Yang, Y.; Li, K.; Cheng, Y.; Wan, D.; Li, M.; You, J. Rhodium-catalyzed annulation of arenes with alkynes through weak chelation-assisted $\mathrm{C}-\mathrm{H}$ activation. Chem. Commun. 2016, 52, 2872-2884. (d) Sambiagio, C.; Schoenbauer, D.; Blieck, R.; Dao-Huy, T.; Pototschnig, G.; Schaaf, P.; Wiesinger, T.; Zia, M. F.; Wencel-Delord, J.; Besset, T.; Maes, B. U. W.; Schnuerch, M. A comprehensive overview of directing groups applied in metal-catalyzed $\mathrm{C}-\mathrm{H}$ functionalization chemistry. Chem. Soc. Rev. 2018, 47, 6603-6743. (e) Banerjee, A.; Santra, 
S. K.; Mohanta, P. R.; Patel, B. K. Ruthenium(II) Catalyzed Regiospecific $\mathrm{C}-\mathrm{H} / \mathrm{O}-\mathrm{H}$ Annulations of Directing Arenes via Weak Coordination. Org. Lett. 2015, 17, 5678-5681. (f) Modi, A.; Sau, P.; Chakraborty, N.; Patel, B. K. A “Thiocarbonyl-Directed" Regiospecific C-H/S-H Annulation of Quinoline4(1H)-thiones with Alkynes. Adv. Synth. Catal. 2019, 361, 13681375 .

(9) (a) Yamaguchi, J.; Yamaguchi, A. D.; Itami, K. C-H Bond Functionalization: Emerging Synthetic Tools for Natural Products and Pharmaceuticals. Angew. Chem. Int. Ed. 2012, 51, 8960-9009. (b) Brueckl, T.; Baxter, R. D.; Ishihara, Y.; Baran, P. S. Innate and Guided C-H Functionalization Logic. Acc. Chem. Res. 2012, 45, 826-839. (c) Hartwig, J. F. Evolution of C$\mathrm{H}$ Bond Functionalization from Methane to Methodology. J. Am. Chem. Soc. 2016, 138, 2-24. (d) Abrams, D. J.; Provencher, P. A.; Sorensen, E. J. Recent applications of C-H functionalization in complex natural product synthesis. Chem. Soc. Rev. 2018, 47, 8925-8967.

(10) (a) Miura, M.; Satoh, T. Arylation reactions via C-H bond cleavage. Top. Organomet. Chem. 2005, 14, 55-83. (b) Jia, C.; Kitamura, T.; Fujiwara, Y. Catalytic Functionalization of Arenes and Alkanes via C-H Bond Activation. Acc. Chem. Res. 2001, 34, 633-639. (c) Bouffard, J.; Itami, K. Rhodium-catalyzed C-H bond arylation of arenes. Top. Curr. Chem. 2010, 292, 231-28o. (d) Ping, Y.; Wang, L.; Ding, Q.; Peng, Y. Nitrile as a Versatile Directing Group for $\mathrm{C}\left(\mathrm{sp}^{2}\right)-\mathrm{H}$ Functionalizations. Adv. Synth. Catal. 2017, 359, 3274-3291. (e) Theveau, L.; Schneider, C.; Fruit, C.; Hoarau, C. Orthogonal PalladiumCatalyzed Direct C-H Bond Arylation of Heteroaromatics with Aryl Halides. ChemCatChem 2016, 8, 3183-3194. (f) Li, B.; Dixneuf, P. H. Ruthenium(II)-Catalysed sp ${ }^{2}$ C-H Bond Functionalization by C-C Bond Formation. Top. Organomet. Chem. 2015, 48, 119-193. (g) Bheeter, C. B.; Chen, L.; Soule, J.-F.; Doucet, H. Regioselectivity in palladium-catalysed direct arylation of 5-membered ring heteroaromatics. Catal. Sci. Technol. 2016, 6, 2005-2049. (h) Sharma, U.; Modak, A.; Maity, S.; Maji, A.; Maiti, D. Direct Arylation via C-H Activation in New Trends in Cross-Coupling: Theory and Applications (Eds.: T. Colacot), RSC, Cambridge, 2014, pp. 551-609. (i) Hussain, I.; Singh, T. Synthesis of biaryls through aromatic C-H bond activation. A review of recent developments. Adv. Synth. Catal. 2014, 356, 1661-1696. (j) Rossi, R.; Bellina, F.; Lessi, M.; Manzini, C. Cross-Coupling of Heteroarenes by $\mathrm{C}-\mathrm{H}$ Functionalization: Recent Progress towards Direct Arylation and Heteroarylation Reactions Involving Heteroarenes Containing One Heteroatom. Adv. Synth. Catal. 2014, 356, 17-117. (k) Zhou, L.; Lu, W. Towards ideal synthesis. Alkenylation of aryl C-H bonds by a Fujiwara-Moritani reaction. Chem. Eur. J. 2014, 20, 634642. (1) Baudoin, O. Transition metal-catalyzed arylation of unactivated $\mathrm{C}\left(\mathrm{sp}^{3}\right)$-H bonds. Chem. Soc. Rev. 2011, 40, 49024911. (m) Saget, T.; Cramer, N. Enantioselective C-H Arylation Strategy for Functionalized Dibenzazepinones with Quaternary Stereocenters. Angew. Chem. Int. Ed. 2013, 52, 7865-7868. (n) Li, S.; Ji, H.; Cai, L.; Li, G. Pd(II)-catalyzed remote regiodivergent ortho- and meta-C-H functionalizations of phenylethylamines. Chem. Sci. 2015, 6, 5595-5600.

(11) (a) Hashimoto, Y.; Hirano, K.; Satoh, T.; Kakiuchi, F.; Miura, M. Ruthenium(II)-Catalyzed Regio- and Stereoselective Hydroarylation of Alkynes via Directed C-H Functionalization. Org. Lett. 2012, 14, 2058-2061. (b) Hashimoto, Y.; Hirano, K.; Satoh, T.; Kakiuchi, F.; Miura, M. Regioselective
$\mathrm{C}-\mathrm{H}$ Bond Cleavage/Alkyne Insertion under Ruthenium Catalysis. J. Org. Chem. 2o13, 78, 638-646.

(12) Collins, K. D.; Lied, F.; Glorius, F. Preparation of conjugated 1,3-enynes by $\mathrm{Rh}(\mathrm{III})$-catalysed alkynylation of alkenes via $\mathrm{C}-\mathrm{H}$ activation. Chem. Commun. 2014, 5o, 4459-4461.

(13) Liu, W.; Ackermann, L. Versatile ruthenium(II)-catalyzed $\mathrm{C}-\mathrm{H}$ cyanations of benzamides. Chem. Commun. 2014, 50, 1878-1881.

(14) Examples of site-selective C-O bond forming reactions via aromatic $\mathrm{C}-\mathrm{H}$ bond functionalizations are also rare, see: (a) Sun, Y.-H.; Sun, T.-Y.; Wu, Y.-D.; Zhang, X.; Rao, Y. A diversity-oriented synthesis of bioactive benzanilides via a regioselective $\mathrm{C}\left(\mathrm{sp}^{2}\right)-\mathrm{H}$ hydroxylation strategy. Chem. Sci. 2016, 7 , 2229-2238. (b)Yuan, Y.-C.; Bruneau, C.; Roisnel, T.; GramageDoria, R. Ru-Catalyzed Selective C-H Bond Hydroxylation of Cyclic Imides. J. Org. Chem. 2019, 84, 1898-1907.

(15) (a) Ackermann, L.; Wang, L.; Wolfram, R.; Lygin, A. V. Ruthenium-Catalyzed Oxidative C-H Alkenylations of Anilides and Benzamides in Water. Org. Lett. 2012, 14, 728-731. (b) Padala, K.; Jeganmohan, M. ortho-Benzoxylation of N-Alkyl Benzamides with Aromatic Acids Catalyzed by Ruthenium(II) Complex. Chem. Eur. J. 2014, 20, 4092-4097. (c) Manikandan, R.; Madasamy, P.; Jeganmohan, M. RutheniumCatalyzed ortho Alkenylation of Aromatics with Alkenes at Room Temperature with Hydrogen Evolution. ACS Catal. 2016, 6, 230-234. (d) Das, R.; Kumar, G. S.; Kapur, M. Amides as Weak Coordinating Groups in Proximal C-H Bond Activation. Eur. J. Org. Chem. 2017, 2017, 5439-5459. (e) Ping, L.; Chung, D. S.; Bouffard, J.; Lee, S.-G. Transition metal-catalyzed site- and regio-divergent $\mathrm{C}-\mathrm{H}$ bond functionalization. Chem. Soc. Rev. 2017, 46, 4299-4328.

(16) (a) Nareddy, P.; Jordan, F.; Brenner-Moyer, S. E.; Szostak, M. Ruthenium(II)-Catalyzed Regioselective C-H Arylation of Cyclic and N,N-Dialkyl Benzamides with Boronic Acids by Weak Coordination. ACS Catal. 2016, 6, 4755-4759. (b) Hashimoto, Y.; Ortloff, T.; Hirano, K.; Satoh, T.; Bolm, C.; Miura, M. $\mathrm{Ru} / \mathrm{Ag}$-catalyzed oxidative alkenylation of benzamides and phenylazoles through regioselective $\mathrm{C}-\mathrm{H}$ bond cleavage. Chem. Lett. 2012, 41, 151-153. (c) Das, R.; Kapur, M. Product Control using Substrate Design: Ruthenium-Catalysed Oxidative C-H Olefinations of Cyclic Weinreb Amides. Chem. Eur. J. 2016, 22, 16986-16990. (d) Das, R.; Kapur, M. Fujiwara-Moritani Reaction of Weinreb Amides using a Ruthenium-Catalyzed C-H Functionalization Reaction. Chem. Asian J. 2015, 10, 1505-1512. (e) Yang, Z.; Qiu, F.-C.; Gao, J.; Li, Z.-W.; Guan, B.T. Palladium-Catalyzed Oxidative Arylation of Tertiary Benzamides: Para-Selectivity of Monosubstituted Arenes. Org. Lett. 2015, 17, 4316-4319. (f) Nareddy, P.; Jordan, F.; Szostak, M. Highly chemoselective ruthenium(II)-catalyzed direct arylation of cyclic and N,N-dialkyl benzamides with aryl silanes. Chem. Sci. 2017, 8, 3204-3210. (g) Huang, Z.; Lim, H. N.; Mo, F.; Young, M. C.; Dong, G. Transition metal-catalyzed ketonedirected or mediated C-H functionalization. Chem. Soc. Rev. 2015, 44, 7764-7786.

(17) (a) Kakiuchi, F.; Kan, S.; Igi, K.; Chatani, N.; Murai, S. A Ruthenium-Catalyzed Reaction of Aromatic Ketones with Arylboronates: A New Method for the Arylation of Aromatic Compounds via C-H Bond Cleavage. J. Am. Chem. Soc. 2003, 125, 1698-1699. (b) Kakiuchi, F.; Matsuura, Y.; Kan, S.; Chatani, 
N. A RuH ${ }_{2}(\mathrm{CO})\left(\mathrm{PPh}_{3}\right)_{3}$-Catalyzed Regioselective Arylation of Aromatic Ketones with Arylboronates via Carbon-Hydrogen Bond Cleavage. J. Am. Chem. Soc. 2005, 127, 5936-5945. (c) Pucheault, M.; Darses, S.; Genet, J.-P. Direct access to ketones from aldehydes via rhodium-catalyzed cross-coupling reaction with potassium trifluoro(organo)borates. J. Am. Chem. Soc. 2004, 126, 15356-15357. (d) Park, Y. J.; Jo, E.-A.; Jun, C.-H. Ruthenium-catalyzed coupling of aldimines with arylboronates: new synthetic method for aromatic ketones. Chem. Commun. 2005, 2005, 1185-1187. (e) Pastine, S. J.; Gribkov, D. V.; Sames, D. sp3 C-H Bond Arylation Directed by Amidine Protecting Group: $\alpha$-Arylation of Pyrrolidines and Piperidines. J. Am. Chem. Soc. 2006, 128, 14220-14221. (f) Nakazono, S.; Easwaramoorthi, S.; Kim, D.; Shinokubo, H.; Osuka, A. Synthesis of arylated perylene bisimides through $\mathrm{C}$ - $\mathrm{H}$ bond cleavage under ruthenium catalysis. Org. Lett. 2009, 11, 5426-5429. (g) Li, H.; Wei, W.; Xu, Y.; Zhang, C.; Wan, X. Ru-catalyzed aerobic oxidative coupling of arylboronic acids with arenes. Chem. Commun. 2o11, 47, 1497-1499. (h) Chinnagolla, R. K.; Jeganmohan, M. Regioselective Ortho-Arylation and Alkenylation of N-Alkyl Benzamides with Boronic Acids via RutheniumCatalyzed C-H Bond Activation: An Easy Route to Fluorenones Synthesis. Org. Lett. 2012, 14, 5246-5249. (i) Chinnagolla, R. K.; Jeganmohan, M. Ruthenium-catalyzed ortho-arylation of acetanilides with aromatic boronic acids. An easy route to prepare phenanthridines and carbazoles. Chem. Commun. 2014, 50, 2442-2444. (j) Zhao, Y.; Snieckus, V. C-H Activation by Amide Chelation Control: Ruthenium-Catalyzed Direct Synthesis of 2-Aryl-3-furanamides. Adv. Synth. Catal. 2014, 356, 1527-1532. (k) Hubrich, J.; Himmler, T.; Rodefeld, L.; Ackermann, L. Ruthenium(II)-catalyzed C-H arylation of anilides with boronic acids, borinic acids and potassium trifluoroborates. Adv. Synth. Catal. 2015, 357, 474-48o. (l) Sollert, C.; Devaraj, K.; Orthaber, A.; Gates, P. J.; Pilarski, L. T. RuCatalysed C-H Arylation of Indoles and Pyrroles with Boronic Acids: Scope and Mechanistic Studies. Chem. Eur. J. 2015, 21, 5380-5386. (m) Hu, F.; Szostak, M. Ruthenium(o)-Catalyzed C-H Arylation of Aromatic Imines under Neutral Conditions: Access to Biaryl Aldehydes. Org. Lett. 2016, 18, 4186-4189. (n) Siopa, F.; Cladera, V.-A. R.; Alfonso, C. A. M.; Oble, J.; Poli, G. Ruthenium-Catalyzed C-H Arylation and Alkenylation of Furfural Imines with Boronates. Eur. J. Org. Chem. 2018, 2018, 6101-6106 and references cited therein.

(18) Gensch, T.; Hopkinson, M. N.; Glorius, F.; Wencel-Delord, J. Mild metal-catalyzed C-H activation: examples and concepts. Chem. Soc. Rev. 2016, 45, 2900-2936.

(19) Manikandan, R.; Jeganmohan, M. Recent advances in the ruthenium(II)-catalyzed chelation-assisted C-H olefination of substituted aromatics, alkenes and heteroaromatics with alkenes via the deprotonation pathway. Chem. Commun. 2017, 53, 8931-8947.

(20) For the only previous synthesis of $\mathbf{2 a}$ reported to date, see: (a) Ahmed, M.; Vernon, J. M. Ring-chain tautomerism of o-benzoylbenzanilides. J. Chem. Soc. Perkin Trans. 1, 1975, 1975, 2048-2051. (b) Heemskerk, J.; Barnes, K. D.; McCall, J. M.; Johnson, G.; Fairfax, D.; Johnson, M. R. Preparation of oxoisoindolinylphenylpropanoates and its analogs for the treatment of spinal muscular atrophy and other uses. PCT Int. Appl. 2007, WO2007 109211 A2 20070927.
(21) (a) Ackermann, L. Carboxylate-Assisted TransitionMetal-Catalyzed C-H Bond Functionalizations: Mechanism and Scope. Chem. Rev. 2011, 111, 1315-1345. (b) Ackermann, L. Carboxylate-Assisted Ruthenium-Catalyzed Alkyne Annulations by $\mathrm{C}-\mathrm{H} / \mathrm{Het}-\mathrm{H}$ Bond Functionalizations. Acc. Chem. Res. 2014, 47, 281-295. (c) Ackermann, L.; Vicente, R.; Potukuchi, H. K.; Pirovano, V. Mechanistic Insight into Direct Arylations with Ruthenium(II) Carboxylate Catalysts. Org. Lett. 2010, 12, 5032-5035. (d) Fabre, I.; von Wolff, N.; Le Duc, G.; Ferrer Flegeau, E.; Bruneau, C.; Dixneuf, P. H.; Jutand, A. Autocatalytic intermolecular versus intramolecular deprotonation in $\mathrm{C}-\mathrm{H}$ bond activation of functionalized arenes by ruthenium(II) or palladium(II) complexes. Chem. Eur. J. 2013, 19, 7595-7604. (e) Ackermann, L.; Vicente, R.; Althammer, A. Assisted Ruthenium-Catalyzed C-H Bond Activation: Carboxylic Acids as Cocatalysts for Generally Applicable Direct Arylations in Apolar Solvents. Org. Lett. 2008, 10, 2299-2302. (f) Ferrer Flegeau, E.; Bruneau, C.; Dixneuf, P. H.; Jutand, A. Autocatalysis for C-H Bond Activation by Ruthenium(II) Complexes in Catalytic Arylation of Functional Arenes. J. Am. Chem. Soc. 2011, 133, 10161-1017o. (g) Arockiam, P. B.; Bruneau, C.; Dixneuf, P. H. Ruthenium(II)-Catalyzed C-H Bond Activation and Functionalization. Chem. Rev. 2012, 112, 5879-5918. (h) Shan, C.; Zhu, L.; Qu, L.-B.; Bai, R.; Lan, Y. Mechanistic view of Ru-catalyzed C-H bond activation and functionalization: computational advances. Chem. Soc. Rev. 2018, 47, 75527576 .

(22) (a) Molander, G. A.; Ellis, N. Organotrifluoroborates: Protected Boronic Acids That Expand the Versatility of the Suzuki Coupling Reaction. Acc. Chem. Res. 2007, 40, 275-286. (b) Darses, S.; Genet, J.-P. Potassium Organotrifluoroborates: New Perspectives in Organic Synthesis. Chem. Rev. 2008, 108, 288-325.

(23) (a) Oi, S.; Fukita, S.; Hirata, N.; Watanuki, N.; Miyano, S.; Inoue, Y. Ruthenium complex-catalyzed direct ortho arylation and alkenylation of 2-arylpyridines with organic halides. Org. Lett. 2001, 3, 2579-2581. (b) Oi, S.; Ogino, Y.; Fukita, S.; Inoue, Y. Ruthenium Complex Catalyzed Direct Ortho Arylation and Alkenylation of Aromatic Imines with Organic Halides. Org. Lett. 2002, 4, 1783-1785. (c) Oi, S.; Aizawa, E.; Ogino, Y.; Inoue, Y. Ortho-selective direct cross-coupling reaction of 2-aryloxazolines and 2-arylimidazolines with aryl and alkenyl halides catalyzed by ruthenium complexes. J. Org. Chem. 2005, 70, 3113-3119. (d) Oi, S.; Sakai, K.; Inoue, Y. RutheniumCatalyzed Arylation of 2-Alkenylpyridines with Aryl Bromides: Alternative E,Z-Selectivity to Mizoroki-Heck Reaction. Org. Lett. 2005, 7, 4009-4011. (e) Ackermann, L.; Born, R.; Alvarez-Bercedo, P. Ruthenium(IV) alkylidenes as precatalysts for direct arylations of alkenes with aryl chlorides and an application to sequential catalysis. Angew. Chem. Int. Ed. 20o7, 46, 6364-6367. (f) Ozdemir, I.; Demir, S.; Cetinkaya, B.; Gourlaouen, C.; Maseras, F.; Bruneau, C.; Dixneuf, P. H. Direct Arylation of Arene C-H Bonds by Cooperative Action of NHCarbene-Ruthenium(II) Catalyst and Carbonate via Proton Abstraction Mechanism. J. Am. Chem. Soc. 20o8, 130, 1156-1157. (g) Pozgan, F.; Dixneuf, P. H. Ruthenium(II) acetate catalyst for direct functionalisation of sp2-C-H bonds with aryl chlorides and access to tris-heterocyclic molecules. Adv. Synth. Catal. 2009, 351, 1737-1743. (h) Prades, A.; Poyatos, M.; Peris, E. ( $\eta^{6}$ Arene)ruthenium(N-heterocyclic carbene) Complexes for the 
Chelation-Assisted Arylation and Deuteration of Arylpyridines: Catalytic Studies and Mechanistic Insights. Adv. Synth. Catal. 2010, 352, 1155-1162. (i) Bruneau, C.; Gramage-Doria, R. One-Pot Directing Group Formation/C-H Bond Functionalization via Copper(I) and Ruthenium(II) Catalysis. Adv. Synth. Catal. 2016, 358, 3847-3856. (j) Nareddy, P.; Jordan, F.; Szostak, M. Recent Developments in Ruthenium-Catalyzed C-H Arylation: Array of Mechanistic Manifolds. ACS Catal. 2017, 7, 5721-5745. (k) Gramage-Doria, R.; Achelle, S.; Bruneau, C.; Robin-le Guen, F.; Dorcet, V.; Roisnel, T. Ruthenium(II)Catalyzed C-H (Hetero)Arylation of Alkenylic 1,n-Diazines (n = 2, 3, and 4): Scope, Mechanism, and Application in Tandem Hydrogenations. J. Org. Chem. 2018, 83, 1462-1477. (1) Gramage-Doria, R.; Roisnel, T. Ruthenium-Catalyzed C-H Bond Heteroarylation of Triazoles Enabled by a Deconvolution Strategy. Eur. J. Org. Chem. 2018, 2018, 6083-6087 and references cited therein.

(24) Yuan, Y.-C.; Kamaraj, R.; Bruneau, C.; Labasque, T.; Roisnel, T.; Gramage-Doria, R. Unmasking Amides: RutheniumCatalyzed Protodecarbonylation of N-Substituted Phthalimide Derivatives. Org. Lett. 2017, 19, 6404-6407.

(25) Zhou, Y.; Chen, P.; Lv, X.; Niu, J.; Wang, Y.; Lei, M.; Hu, L. A facile and efficient method for the synthesis of N-substituted isoindolin-1-one derivatives under $\mathrm{Pd}(\mathrm{OAc})_{2} / \mathrm{HCOOH}$ system. Tetrahedron Lett. 2017, 58, 2232-2235.

(26) Kim, E.; Jeong, M.; Lee, B. M.; Kim, B. H. One-Pot Synthesis of Isoindolin-1-ones from Nitroarenes and o-Phthalaldehyde via Indium-Mediated Reductive Condensation Reactions. Heterocycles 2018, 96, 1759-1770.

(27) Lin, C.; Zhen, L.; Cheng, Y.; Du, H.-J.; Zhao, H.; Wen, X.; Kong, L.-Y.; Xu, Q.-L.; Sun, H. Visible Light-Induced Isoindole Formation To Trigger Intermolecular Diels-Alder Reactions in the Presence of Air. Org. Lett. 2015, 17, 2684-2687.

(28) Hsieh, J.-C.; Cheng, C.-H. Nickel-catalyzed coupling of isocyanates with 1,3-iodo esters and halobenzenes: a novel method for the synthesis of imide and amide derivatives. Chem. Commun. 2005, 36, 4554-4556.

(29) Kaminski, K.; Wiklik, B.; Obniska, J. Synthesis, Anticonvulsant Properties, and SAR Analysis of Differently Substituted Pyrrolidine-2,5-diones and Piperidine-2,6-diones. Arch. Pharm. Chem. Life Sci. 2014, 347, 840-852.

(30) Vogler, T.; Studer, A. Rhodium-catalyzed oxidative homocoupling of boronic acids. Adv. Synth. Catal. 20o8, 350, $1963-1967$.

(31) Verma, A.; Patel, S.; Meenakshi; Kumar, A.; Yadav, A.; Kumar, S.; Jana, S.; Sharma, S.; Prasad, C. D.; Kumar, S. Transition metal free intramolecular selective oxidative $C\left(\mathrm{sp}^{3}\right)-\mathrm{N}$ coupling: synthesis of $\mathrm{N}$-aryl-isoindolinones from 2-alkylbenzamides. Chem. Commun. 2015, 51, 1371-1374.

(32) T. Thatikonda, S. K. Deepake, U. Das, $\alpha$-Angelica Lactone in a New Role: Facile Access to N-Aryl Tetrahydroisoquinolinones and Isoindolinones via Organocatalytic $\alpha-\mathrm{CH}_{2}$ Oxygenation. Org. Lett. 2019, 21, 2532-2535. 